\title{
A Review of the Progress of Thin-Film Transistors and Their Technologies for Flexible Electronics
}

\author{
Mohammad Javad Mirshojaeian Hosseini ${ }^{t, \ddagger}$ and Robert A. Nawrocki ${ }^{*, \ddagger}$ \\ School of Engineering Technology, Purdue University, West Lafayette, IN 47907, USA; mmirshoj@purdue.edu \\ * Correspondence: robertnawrocki@purdue.edu \\ † Current address: 401 N Grant St., West Lafayette, IN 47907, USA. \\ $\ddagger$ These authors contributed equally to this work.
}

check for updates

Citation: Mirshojaeian Hosseini, M.J.; Nawrocki, R.A. A Review of the Progress of Thin-Film Transistors and Their Technologies for Flexible Electronics. Micromachines 2021, 12, 655. https://doi.org/ $10.3390 / \mathrm{mi} 12060655$

Academic Editor: Joohoon Kang

Received: 17 May 2021

Accepted: 27 May 2021

Published: 2 June 2021

Publisher's Note: MDPI stays neutral with regard to jurisdictional claims in published maps and institutional affiliations.

Copyright: (C) 2021 by the authors. Licensee MDPI, Basel, Switzerland. This article is an open access article distributed under the terms and conditions of the Creative Commons Attribution (CC BY) license (https:// creativecommons.org/licenses/by/ $4.0 /)$.

\begin{abstract}
Flexible electronics enable various technologies to be integrated into daily life and fuel the quests to develop revolutionary applications, such as artificial skins, intelligent textiles, e-skin patches, and on-skin displays. Mechanical characteristics, including the total thickness and the bending radius, are of paramount importance for physically flexible electronics. However, the limitation regarding semiconductor fabrication challenges the mechanical flexibility of thin-film electronics. Thin-Film Transistors (TFTs) are a key component in thin-film electronics that restrict the flexibility of thin-film systems. Here, we provide a brief overview of the trends of the last three decades in the physical flexibility of various semiconducting technologies, including amorphous-silicon, polycrystalline silicon, oxides, carbon nanotubes, and organics. The study demonstrates the trends of the mechanical properties, including the total thickness and the bending radius, and provides a vision for the future of flexible TFTs.
\end{abstract}

Keywords: TFT; flexible TFT; total thickness; bending radius (radii); oxides; amorphous Silicon (a-Si); Polycrystalline Silicon (Poly-Si); carbon nanotube (CNT); organic semiconductors

\section{Introduction}

Physically flexible electronics enable frontier technologies to provide novel ways to interact with the physical world and open the doors toward innovative applications, such as wearable devices [1-4], electronic skins (e-skin) [5-7], foldable displays [8,9], and electronic papers [10-12]. The advantages of flexible electronics include interfacial conformability, bendability, stretchability, and being lightweight [13]. Compared with inorganic materials (e.g., metals or oxides) biocompatible organic semiconductors can be safely used for cutaneous and sub-cutaneous applications without causing harmful side effects [14].

There are three main approaches toward flexibility in electronic devices. The first approach (Figure 1a) relies on the fabrication of distributed components on individual "islands" that are electrically and mechanically connected with individual "springs". The main benefits of this approach are the use of high performance inorganic electronics [5]. However, a high fabrication cost is the main drawback. The second method (Figure 1b) centers around the use of intrinsically flexible and stretchable materials (Young's modulus in the range of MPa) that are typically organic. The organic materials bear a strain over 100\%; however, the intrinsically flexible materials suffer from relatively poor electrical properties (e.g., low carrier mobilities, high OFF current, and high threshold voltage), poor device stability, and restricted choice of materials [15].

The third alternative (Figure 1c) is based on the use of non-stretchable, hard, but ultra-thin materials (Young's modulus in the range of GPa). Here, a thin film (typically few micrometers or less) is laminated on a pre-stretched elastomer, which is then allowed to relaxed. The ultra thin film buckles due to the differences in Young's moduli. Subsequently, the structure can be repeatedly stretched up to the initial limit [16]. This method benefits from higher, full electronic interconnectivity, compared to isolated islands. However, the electronic materials 
used typically exhibit carrier mobilities that are orders of magnitude less compared with crystalline silicon [17].

In this review, we concentrate on the ultra-thin film approach to flexible electronics. The trends in other approaches, namely microspring-connected islands and intrinsically stretchable materials, are discussed elsewhere.

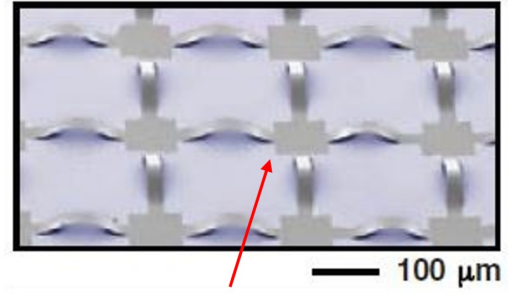

Isolated islands

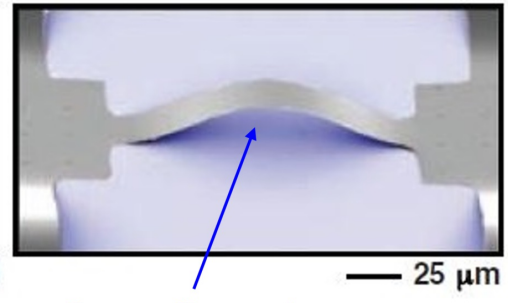

Connecting springs

(a)

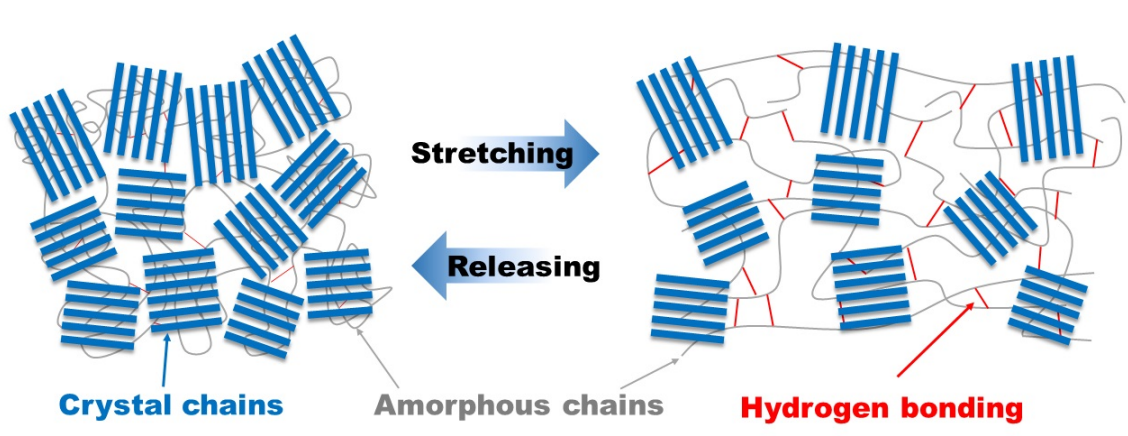

(b)

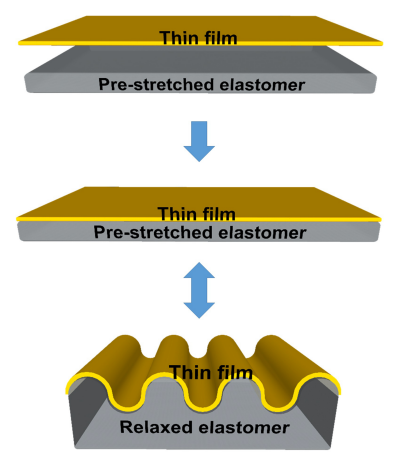

(c)

Figure 1. Three main approaches to physically flexible electronics; (a) rigid islands connected with micro-springs [5], (b) intrinsically stretchable materials, and (c) ultra-thin electronics laminated on soft and stretchable substrates. Reproduced with permission.

The definition of flexibility varies across applications, from rolling in solar cells to conforming to human skin as an electrode (Figure 2) [18]. However, the bendability of a thin film is defined by its bending stiffness, which is mainly the function of two factors, the Young's modulus and the total thickness of the thin film. A thinner film (smaller magnitude of $a_{i}$ ) or smaller Young's modulus results in a more conformal film to the underlying substrate (smaller magnitude of $t_{i}$ ); in general, $a_{1}>a_{2}>a_{3}>a_{4}$ results in $t_{1}>t_{2}>t_{3}>$ $t_{4}$ [19]. As the material choice is often dictated by technological constraints via the choice of the semiconducting material, a reduction of the Young's modulus is often difficult or impossible. Hence, engineers often rely on reducing the total film thickness to improve the conformability.
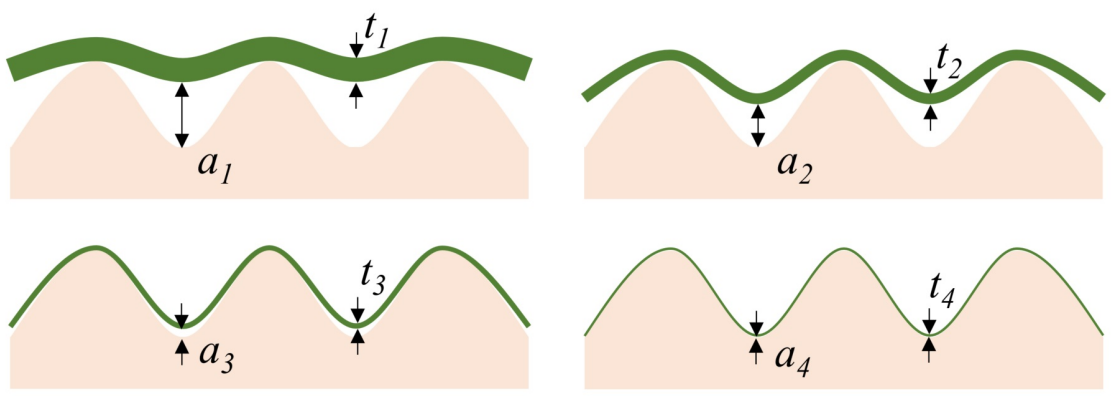

Figure 2. Reduction of the total film thickness reduces air gaps and improves the conformal contact between the film and the substrate. 
Thin film transistors are essential devices among flexible electronic components. They are widely used in applications, such as flexible displays [20-22], intelligent textiles [23], and conformable radio frequency identification devices (RFID) [24]. It is the choice of the semiconductor material that defines the device technology as well as its manufacturing constraints (e.g., the choice of substrate, fabrication equipment) and mechanical (i.e., flexibility) and electrical (i.e., carrier mobilities) characteristics.

Hydrogenated amorphous silicon (a-Si:H) Thin-Film Transistors (TFTs) have been considered as a driving element in flexible displays [8,9] due to the low temperature $\left(<300^{\circ} \mathrm{C}\right)$ of the fabrication process and better uniformities of TFT properties compared to polycrystalline silicon (Poly-Si) TFTs $[25,26]$. However, instability under gate-biased stress restricts their applications in flexible devices [27].

Low-Temperature Poly-Silicon (LTPS) is a promising candidate for high frame rates and high-resolution flexible displays due to the high mobility and stable characteristics compared to a-Si:H [28]. Nevertheless, the higher temperature of Poly-Si crystallization compared with the glass transition temperature of plastic limits LTPS realization [29].

Amorphous oxide semiconductors, such as amorphous Indium Gallium Zinc Oxide and Zinc Tin Oxide, have been studied intensively due to their higher stability and better mobility compared with a-Si:H and superior uniformity over larger substrates compared to LTPS [30]. However, the higher carrier concentration of amorphous oxide semiconductors lowers the ON/OFF ratio compared to other semiconductors [31].

Single-Wall Carbon Nanotube (SWCNT) semiconductors offer flexibility, transparency, low-cost, and room temperature fabrication, as well as high intrinsic mobility [32]. Despite all the advantages, SWCNT TFTs suffer from a complex and expensive fabrication processes, uncertainty in the device uniformity, and reproducibility issues [33,34].

Organic Thin-Film Transistors (OTFTs) have demonstrated relatively low fabrication temperature $\left(<120{ }^{\circ} \mathrm{C}\right)$, lower fabrication costs comparing to inorganic materials, alternative fabrication methods, such as inkjet printing, and remarkable flexibility [35]. However, organic semiconductors suffer from poor electrical properties and stability [36].

Here, we review the progress of the total thickness and bending radius of five categories of TFTs based on semiconductors consisting of a-Si:H, Poly-Si, oxides, CNT, and organic materials over the last three decades. The electrical properties, such as the on/off ratio and mobility will also be studied. The fabrication process, device architecture, and the application of every category are also investigated.

\section{Hydrogenated Amorphous Silicon}

The first demonstration of flexible hydrogenated amorphous silicon devices dates back in 1983 when Okinawa et al. fabricated an a-Si:H solar cell on a plastic substrate [37]. Since 1986, when the first a-Si:H-based LCD appeared, bendable displays have been considered the main application of hydrogenated amorphous silicon TFTs [38]. Plasma-Enhanced Chemical Vapor Deposition (PECVD) is mainly used to deposit a-Si:H, and plasma keeps the decomposition temperature of $\mathrm{SiH} 4$ lower than $300{ }^{\circ} \mathrm{C}$ [39]. The mobility of TFTs using PECVD techniques reaches $0.5-1 \mathrm{~cm}^{2} / \mathrm{Vs}$ for electrons and approximately $10^{-2} \mathrm{~cm}^{2} / \mathrm{Vs}$ for holes [40].

However, technologies, such as Hot Wire Chemical Vapor Deposition (HWCVD), offer the mobility of $4.7 \mathrm{~cm}^{2} / \mathrm{Vs}$ for a-Si:H TFTs, yet such fabrication techniques are still not fully commercialized [41,42]. The typical a-Si:H TFT structure is bottom-gate, staggered, and Bach Channel Etched (BCE) which has advantages in fabrication procedures [27]. The leakage current is in the range of $10^{-12} \mathrm{~A}$, and the long-term reliability of TFTs is lower than that of LTPS devices [43].

The a-Si:H TFT typically has an ON/OFF ratio over $10^{6}$, a threshold voltage of less than $3 \mathrm{~V}$, and a sub-threshold slope less than $0.5 \mathrm{~V} / \mathrm{dec}$ [44]. The threshold voltage of a-Si:H TFTs shows instability under immense stress for a prolonged time due to the creation of dangling bonds and charge trapping [45]. They have a lower mobility compared to other semiconductors, such as LTPS, a limited high speed, and large-current applications [46]. 
Figure 3 demonstrates a subset of studies illustrating the progress regarding the thickness and bending radius over the last three decades [47-54]. Shen et al. reported an a-Si:H over a $50 \mu \mathrm{m}$ alkali-free glass foil in 1996 . In 1997, Shen et al. demonstrated a network of a-Si:H TFT for backplanes of active-matrix liquid crystal displays using the same structure. Sturm et al. realized and characterized a network of hydrogenated amorphous silicon transistors distributed across a $50 \mu \mathrm{m}$ polyimide (PI) substrate in the following years.

The bending radius is estimated at $55 \mathrm{~mm}$. Jang et al. presented a flexible TFT device based on a-Si:H that showed the same electrical characteristics as rigid devices in 2008 . They fabricated the device over a $150 \mu \mathrm{m}$ stainless steel foil, and the bending radii reached $12.5 \mathrm{~mm}$. In 2012, Fruehauf et al. introduced the most bendable TFTs based on a:Si:H with a bending radius of $5 \mathrm{~mm}$ over a $75 \mu \mathrm{m}$ glass foil. In the following years, TFTs became thinner, as low as $26.22 \mu \mathrm{m}$; however, the lowest bending radius remained unchanged. Table 1 lists the main electrical and mechanical characteristics of amorphous silicon devices with Figure 4 showing an example of flexible a-Si:H TFTs.

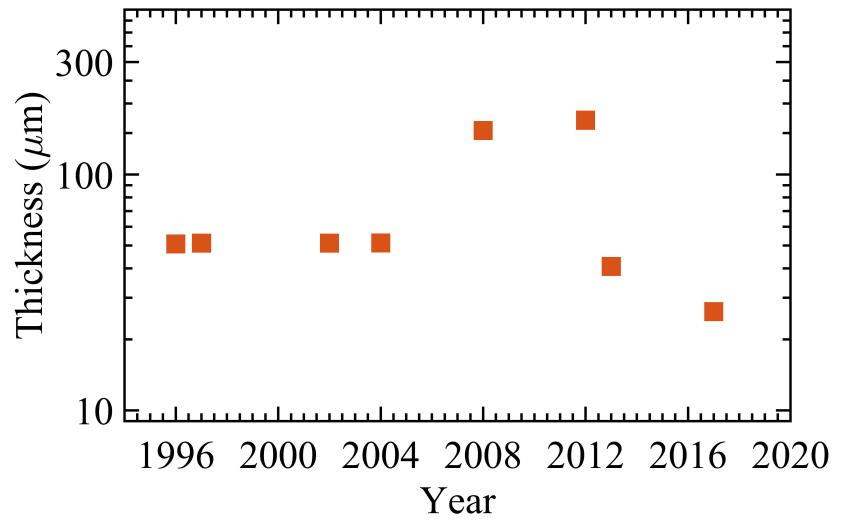

(a)

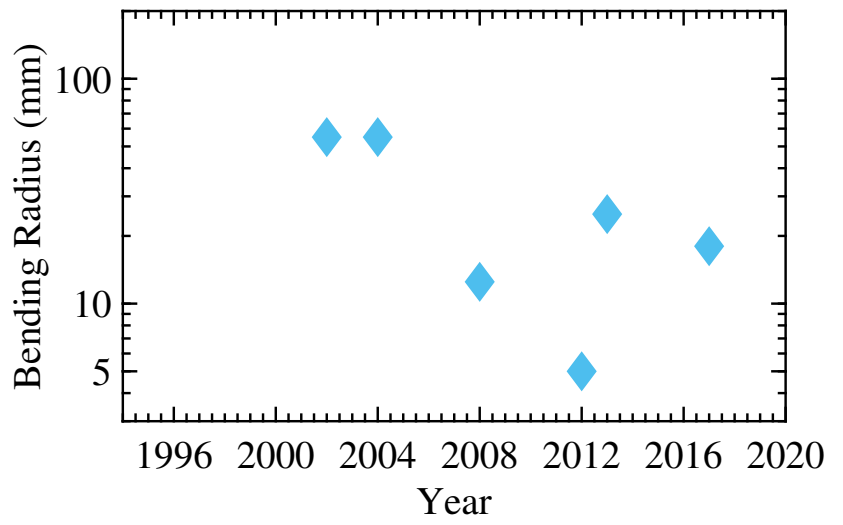

(b)

Figure 3. The progress of hydrogenated amorphous silicon (a-Si:H) Thin-Film Transistors (TFTs) with (a) the total thickness and $(\mathbf{b})$ the bending radius.

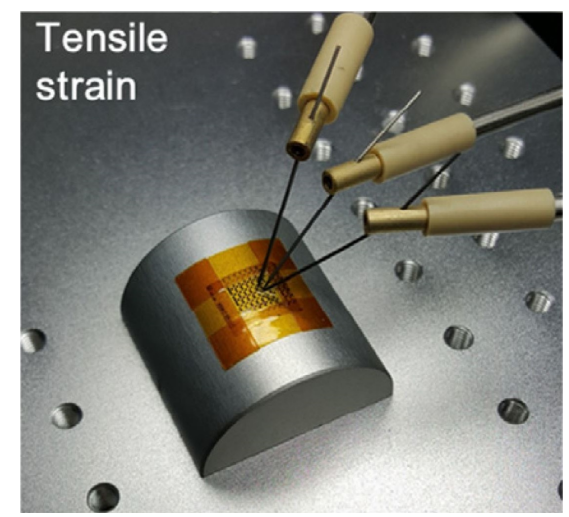

(a)

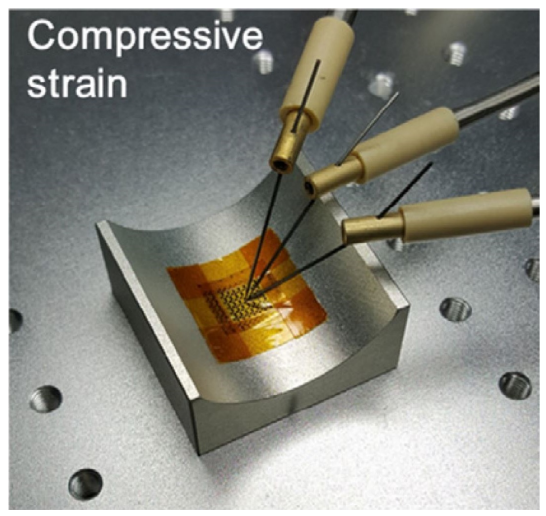

(b)

Figure 4. An example of physically flexible a-Si:H transistors under (a) tensile and (b) compressive strain [54]. Reproduced with permission. 
Table 1. The detailed properties of the a-Si:H TFTs in Figure 3.

\begin{tabular}{ccccccccccc}
\hline $\begin{array}{c}\text { Publication } \\
\text { Year }\end{array}$ & $\begin{array}{c}\text { Bending } \\
\text { Radius } \\
(\mathbf{m m})\end{array}$ & $\begin{array}{c}\text { Total } \\
\text { Thickness } \\
(\boldsymbol{\mu m})\end{array}$ & $\begin{array}{c}\text { ON/OFF } \\
\text { Ratio }\end{array}$ & $\begin{array}{c}\text { Channel } \\
\text { Width/ } \\
\text { Length }\end{array}$ & $\begin{array}{c}\text { Mobility } \\
\left(\mathbf{c m}^{2} / \mathbf{V s}\right)\end{array}$ & Substrate & $\begin{array}{c}\text { Substrate } \\
\text { Thickness } \\
(\boldsymbol{\mu m})\end{array}$ & Dielectric & Reference \\
\hline 1996 & 65 & 50.75 & $10^{4}$ & $1000 / 100$ & N/A & $\begin{array}{c}\text { alkali-free } \\
\text { glass foil }\end{array}$ & 50 & $\mathrm{SiN}_{x}$ & {$[47]$} \\
1997 & 65 & 51.15 & $10^{6}$ & $500 / 150$ & 0.41 & $\begin{array}{c}\text { alkali-free } \\
\text { glass foil }\end{array}$ & 50 & $\mathrm{SiN}_{x}$ & {$[48]$} \\
2002 & 55 & 51.16 & $10^{5}$ & $14 / 4$ & 0.47 & PI & 50 & $\mathrm{SiN}_{x}$ & {$[49]$} \\
2004 & 55 & 51.26 & $10^{5}$ & $25 / 10$ & 0.42 & PI & 50 & $\mathrm{SiN}_{x}$ & {$[50]$} \\
2008 & 12.5 & 153.7 & $10^{6}$ & $25 / 5$ & 1.47 & $\begin{array}{c}\text { stainless } \\
\text { steel foil }\end{array}$ & 150 & $\mathrm{SiN}_{x}$ & {$[51]$} \\
2012 & 5 & 75 & $10^{6}$ & $50 / 10$ & 0.4 & $\begin{array}{c}\text { glass foil } \\
\text { PI over }\end{array}$ & 75 & $\mathrm{SiN}_{x}$ & {$[52]$} \\
2013 & 25 & 40.75 & $10^{7}$ & $80 / 8$ & 0.45 & glass foil & 40 & $\mathrm{SiN}_{x}$ & {$[53]$} \\
2017 & 18 & 26.22 & $10^{4}$ & $10 / 10$ & 0.031 & PI & 25 & $\mathrm{SiN}_{x}$ & {$[54]$} \\
\hline
\end{tabular}

\section{Polycrystalline Silicon}

In 1984, Harbeke et al. showed that poly-Si had higher stability with lower roughness compared with a-Si [55]. However, the deposition process (Low-Pressure Chemical Vapor Deposition followed by thermal recrystallization) temperature reached $1000{ }^{\circ} \mathrm{C}$, which made using plastic substrates impossible [56]. The introduction of the $\mathrm{XeCl}$ excimer laser in 1986 reduced the maximum temperature of the process to less than $260^{\circ} \mathrm{C}$, but the temperature was still higher than the melting temperature of most plastic substrates [57].

In the following years, the crystallization methods, such as Excimer Laser Annealing (ELA), Solid Phase Crystallization (SPC), and Sequential Lateral Solidification (SLS) opened the doors to deploying plastic substrates [58]. The Low-Temperature Polycrystalline silicon TFTs offers carrier mobility of 20 to $500 \mathrm{~cm}^{2} /$ Vs and the leakage current of $10^{-12}$ A makes it a promising candidate for bendable display industries [59]. Furthermore, the higher thermal conductivity of LTPS $(32 \mathrm{~W} / \mathrm{mK})$ protects it from self-induced thermal degradation, compared to other semiconductors, such as metal oxide semiconductors with a thermal conductivity of $1.4 \mathrm{~W} / \mathrm{mK}[60,61]$.

In-grain defects and nonuniform distribution of the grain boundaries along the device channel lead to the variation in threshold voltages from device to device over the same substrate and limits in deploying LTPS TFTs for analog circuits. Moreover, the process temperature is still challenging for the majority of plastic substrates [62].

The downward trend of the total thickness and bending radius of LTPS TFTs since the 1990s is shown in Figure 5 [63-71]. Sigmon et al. reported one of the earliest LTPS devices on a 175- $\mu$ m polyester substrate in 1997. The following year, King et al. demonstrated a device with the same thickness fabricated on a Polyethylene Terephthalate (PET) substrate that showed a higher ON/OFF ratio. Omata et al. recorded the highest mobility for a flexible device in 1999 using a 100- $\mu \mathrm{m}$ stainless steel substrate. The bending radius for the device was estimated at $20 \mathrm{~mm}$. Three years later, in 2002, Shimoda et al. developed a flexible Liquid Chrystal Display (LCD) based on LTPS TFTs. The device was fabricated on a 400- $\mu \mathrm{m}$ Polyethersulfone (PES) substrate, and the bending radius was $20 \mathrm{~mm}$.

Fonash et al. introduced a fabrication method based on a separation technique to keep the mobility as high as $174 \mathrm{~cm}^{2} / \mathrm{Vs}$, while the thickness decreased to $20 \mu \mathrm{m}$. In 2007, Fortunato et al. reported the thinnest LTPS TFT fabricated on an $8-\mu \mathrm{m}$ PI bent to $13 \mathrm{~mm}$. Kim et al. from Samsung R\&D center reported a 2.8-inch flexible display based on LTPS TFT on a $240-\mu \mathrm{m}$ substrate. The bending radius of the display reached $10 \mathrm{~mm}$.

Bearzotti et al. demonstrated a network of LTPS inverters beside three sensory units in 2011. The device was fabricated on an $8-\mu \mathrm{m}$ PI substrate, and the bending radius was as low as $6 \mathrm{~mm}$. The most bendable LTPS TFT was shown in 2019 by Park with the reported thickness of $18.05 \mu \mathrm{m}$ and bending radii of $2 \mathrm{~mm}$. Table 2 summarizes the main electrical 
and mechanical properties of the polycrystalline silicon devices shown in Figure 5, with

Figure 6 showing an early example of flexible LTPS TFTs.

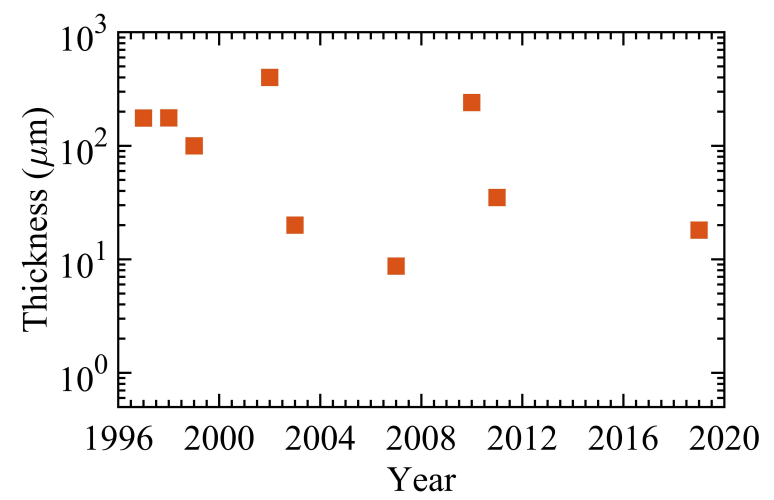

(a)

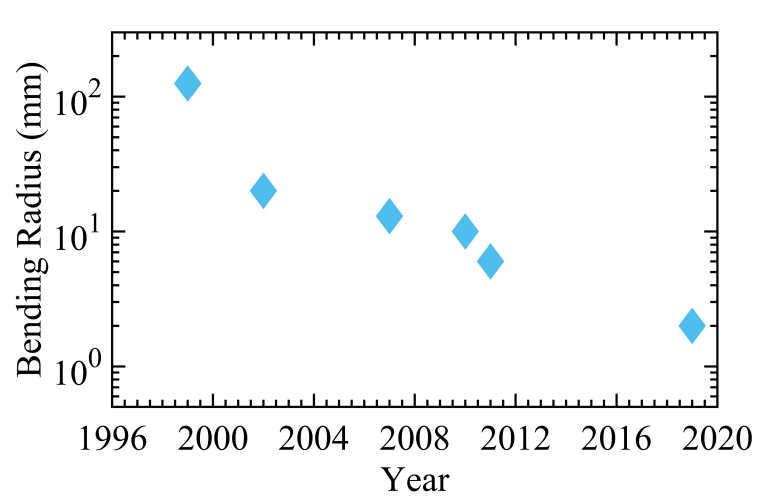

(b)

Figure 5. The progress of LTPS TFTs with (a) the total thickness and (b) the bending radius.

Table 2. The detailed properties of the LTPS TFTs in Figure 5.

\begin{tabular}{|c|c|c|c|c|c|c|c|c|c|}
\hline $\begin{array}{l}\text { Publication } \\
\text { Year }\end{array}$ & $\begin{array}{c}\text { Bending } \\
\text { Radius } \\
(\mathrm{mm})\end{array}$ & $\begin{array}{c}\text { Total } \\
\text { Thickness } \\
\quad(\mu \mathrm{m})\end{array}$ & $\begin{array}{l}\text { ON/OFF } \\
\text { Ratio }\end{array}$ & $\begin{array}{c}\text { Channel } \\
\text { Width/ } \\
\text { Length }\end{array}$ & $\begin{array}{l}\text { Mobility } \\
\left(\mathrm{cm}^{2} / \mathrm{Vs}\right)\end{array}$ & Substrate & $\begin{array}{c}\text { Substrate } \\
\text { Thickness } \\
\quad(\mu \mathrm{m})\end{array}$ & Dielectric & Reference \\
\hline 1997 & $\mathrm{~N} / \mathrm{A}$ & 175.6 & $>10^{3}$ & $\mathrm{~N} / \mathrm{A}$ & $\mathrm{N} / \mathrm{A}$ & Polyester & 175 & $\mathrm{SiO}_{2}$ & [63] \\
\hline 1998 & $\mathrm{~N} / \mathrm{A}$ & 176.11 & $>10^{5}$ & $100 / 50$ & 60 & PET & 175 & $\mathrm{SiO}_{2}$ & [64] \\
\hline 1999 & 125 & $>100$ & $10^{6}$ & $\mathrm{~N} / \mathrm{A}$ & 106 & $\begin{array}{c}\text { stainless } \\
\text { steel }\end{array}$ & 100 & $\mathrm{SiO}_{2}$ & [65] \\
\hline 2002 & 20 & $>400$ & $\mathrm{~N} / \mathrm{A}$ & $10 / 10$ & 63 & PES & 400 & $\mathrm{SiO}_{2}$ & [66] \\
\hline 2003 & $\mathrm{~N} / \mathrm{A}$ & $>20$ & $10^{8}$ & $\mathrm{~N} / \mathrm{A}$ & 174 & $\mathrm{~N} / \mathrm{A}$ & 20 & $\mathrm{SiO}_{2}$ & [67] \\
\hline 2007 & 13 & 8.695 & $>10^{6}$ & $\mathrm{~N} / \mathrm{A}$ & 70 & PI & 8 & $\mathrm{SiO}_{2}$ & [68] \\
\hline 2010 & 10 & $>240$ & $10^{8}$ & $\mathrm{~N} / \mathrm{A}$ & 124 & $\mathrm{~N} / \mathrm{A}$ & 240 & $\mathrm{SiO}_{2}$ & [69] \\
\hline 2011 & 6 & 35 & $\mathrm{~N} / \mathrm{A}$ & $150 / 10$ & 60 & PI & 10 & $\mathrm{SiO}_{2}$ & [70] \\
\hline 2019 & 2 & 18.05 & $>10^{7}$ & $\begin{array}{c}5 / 4 \text { and } \\
10 / 6\end{array}$ & 80 & PI & 17 & $\mathrm{SiO}_{2}$ & [71] \\
\hline
\end{tabular}

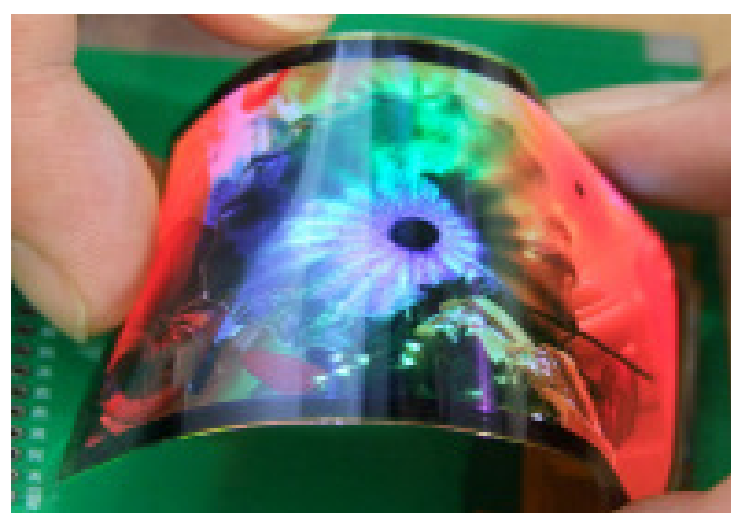

(a)

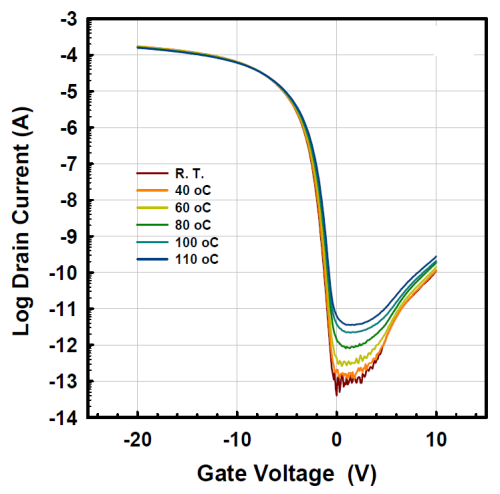

(b)

Figure 6. An example of one of the original physically flexible LTPS TFTs [69]. (a) Photograph of a flexible substrate with TFTs and circuits. (b). Transfer curve of a since LTPS device. Reproduced with permission. 


\section{Oxides}

Since the first demonstration of amorphous Indium-Gallium-Zinc-Oxide (a-IGZO) in 2003-2004 [72,73], oxide semiconductors have attracted a significant amount of attention in flexible electronics areas due to their optical transparency, high carrier mobility, and lower process temperature compared with a-Si [74]. There are four more oxide semiconductors in addition to a-IGZO that have been deployed to realize flexible oxide TFTs, namely Zinc Oxide (ZnO), Zinc Tin Oxide (ZTO), Indium Zinc Oxide (IZO), and Zinc Indium Tin Oxide (ZITO) [75]. Sputtering is the dominant technology to deposit oxides [76]; however, other methods, such as printing [77], spin coating [78], and Pulsed Laser Deposition (PLD) [79], have also been reported.

The application of metal oxide TFTs has been reported mostly for bendable/paper displays [80,81], wearable sensors [82], flexible memories [83,84], and energy storage [85]. While the maximum reported mobility for oxides surpasses $150 \mathrm{~cm}^{2} / \mathrm{Vs}$, it is commonly in the range of 1 to $100 \mathrm{~cm}^{2} / \mathrm{Vs}$ [86]. The leakage current for oxide TFTs is as low as $10^{-13}$ A [30]. Polyimide (PI), polycarbonate (PC), polyethylene terephthalate (PET), and polyethylene naphthalate (PEN) are the most commonly plastic substrates for oxide TFTs [87], while other plastics, such as polydimethylsiloxane (PDMS) [88], polyurethane (PU) [89], and thin glass foil [90], are rarely used.

The oxide semiconductors are deposited at room temperature; however, the TFT processing temperature, particularly for dielectric fabrication, is in excess of $150{ }^{\circ} \mathrm{C}$ making oxide TFTs incompatible with transparent plastics, such as cyclo-olefins. The higher carrier concentration of amorphous oxide semiconductors typically offers lower ON/OFF ratios compared to other semiconductors [31].

Figure 7 presents the trends in oxide TFTs, demonstrating the total thickness and the bending radius since 2004 [73,91-95]. Hosono et al. reported one of the earliest amorphous IGZO (a-IGZO) TFTs on a $200 \mu \mathrm{m}$ PET substrate with a bending radii of $30 \mathrm{~mm}$. In 2006, a ZTO TFT was fabricated by Hauschildt et al. on a stainless steel-backed PI sheet with an overall thickness of $50.56 \mu \mathrm{m}$. Three years later, a light-emitting diode display was shown by Chung et al. based on a-IGZO TFT on a 10- $\mu \mathrm{m}$ PI. The display showed a bending radius of $3 \mathrm{~mm}$. In 2010, Moon et al. introduced a flexible, solution-based oxide TFT based on Zinc oxide with a bending radius of $0.2 \mathrm{~mm}$ and a thickness of approximately $50 \mu \mathrm{m}$.

Tröster et al. demonstrated an ultra-flexible TFT based on a-IGZO that was capable of wrapping around a human hair with a bending radius of $50 \mu \mathrm{m}$. The device was fabricated on the thinnest reported substrate for oxide TFTs with $1.145 \mu \mathrm{m}$ using polydimethylsiloxane (PDMS). In 2017, the most bendable oxide TFT was demonstrated with a bending radius of $13 \mu \mathrm{m}$ and a total thickness of $80.385 \mu \mathrm{m}$. Table 3 shows the detailed properties of the oxide TFTs shown in Figure 7, with Figure 8 showing a recent example of an array of flexible oxide (IGZO) TFTs.

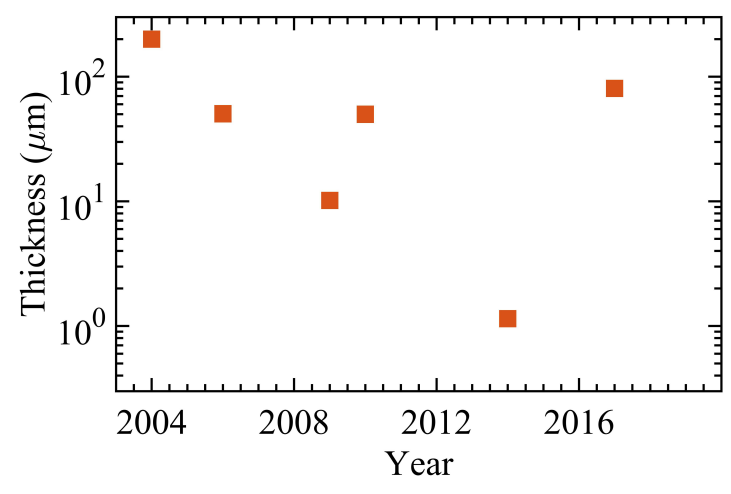

(a)

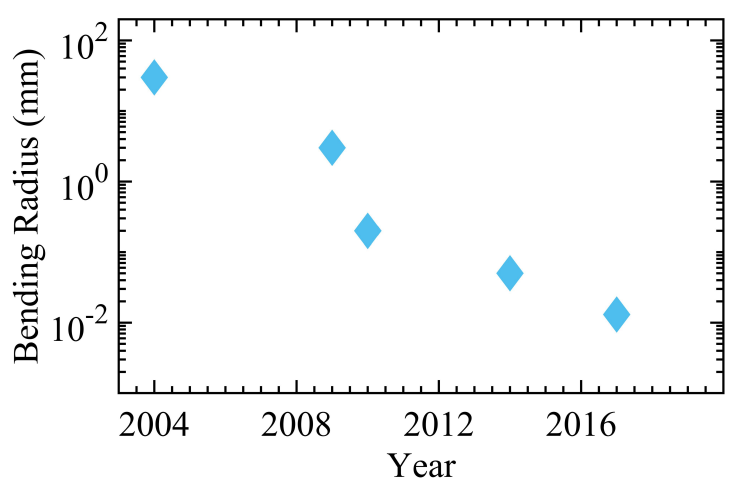

(b)

Figure 7. The progress of oxide TFTs with (a) the total thickness and (b) the bending radius. 


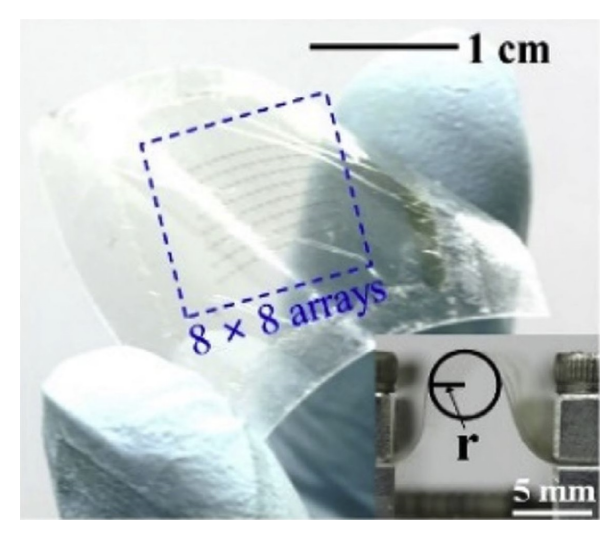

(a)

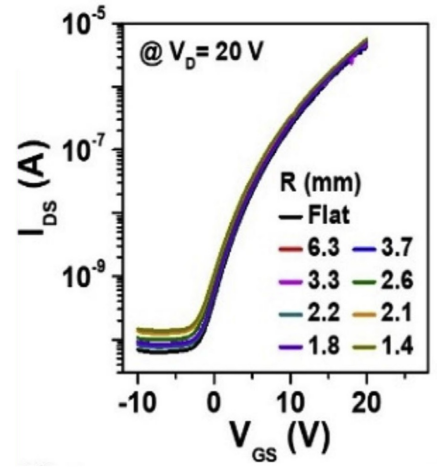

(b)

Figure 8. (a) Manual mechanical bending of an IGZO TFT film. The inset shows a zoomed view of the bent film (b) Transfer curve of the IGZO TFTs for different bending radii [96]. Reproduced with permission.

Table 3. The detailed properties of the oxide TFTs in Figure 7.

\begin{tabular}{|c|c|c|c|c|c|c|c|c|c|c|}
\hline $\begin{array}{l}\text { Publication } \\
\text { Year }\end{array}$ & $\begin{array}{c}\text { Bending } \\
\text { Radius } \\
(\mathrm{mm})\end{array}$ & $\begin{array}{c}\text { Total } \\
\text { Thickness } \\
(\mu \mathrm{m})\end{array}$ & $\begin{array}{c}\text { ON/OFF } \\
\text { Ratio }\end{array}$ & $\begin{array}{c}\text { Channel } \\
\text { Width/Length }\end{array}$ & $\begin{array}{l}\text { Mobility } \\
\left(\mathrm{cm}^{2} / \mathrm{Vs}\right)\end{array}$ & Substrate & $\begin{array}{c}\text { Substrate } \\
\text { Thickness } \\
\quad(\mu \mathrm{m})\end{array}$ & Dielectric & Semiconductor & Reference \\
\hline 2004 & 30 & $>200$ & $10^{3}$ & $200 / 50$ & $6-9$ & $\begin{array}{c}\text { PET } \\
\text { stainless }\end{array}$ & 200 & $\mathrm{Y}_{2} \mathrm{O}_{3}$ & a-IGZO & [73] \\
\hline 2006 & $\mathrm{~N} / \mathrm{A}$ & 50.56 & $10^{6}$ & $1000 / 80$ & 14 & $\begin{array}{c}\text { steel } \\
\text { foil-backed } \\
\text { PI }\end{array}$ & 50 & $\mathrm{SiON}$ & ZTO & [91] \\
\hline 2009 & 3 & 10.15 & $>10^{8}$ & $\mathrm{~N} / \mathrm{A}$ & 15.1 & PI & 10 & $\mathrm{SiN}_{x}$ & a-IGZO & [92] \\
\hline 2010 & 0.2 & $>50$ & $10^{6}$ & $1500 / 120$ & $\begin{array}{c}0.39 \pm \\
0.03\end{array}$ & PI & 50 & $\mathrm{SiO}_{2}$ & $\mathrm{ZnO}$ & [93] \\
\hline 2014 & 0.05 & 1.145 & $10^{6}$ & $280 / 80$ & 26 & Parylene & 1 & $\mathrm{Al}_{2} \mathrm{O}_{3}$ & a-IGZO & [94] \\
\hline 2017 & 0.013 & 80.385 & $10^{7}$ & $280 / 30$ & 13.7 & PDMS & 80 & $\mathrm{Al}_{2} \mathrm{O}_{3}$ & a-IGZO & [95] \\
\hline
\end{tabular}

\section{Carbon Nanotubes}

In 1998, two separate research groups demonstrated thin-film transistors based on single and multi-wall carbon nanotubes on silicon substrates [97,98]. Rinzler et al. presented a process to deposit a SWCNT film on a flexible substrate for the first time in 2004 [99]. The properties of SWCNTs, such as small geometric size $(\approx 1 \mathrm{~nm})$, low power dissipation due to the possibility of ballistic transport, and good thermal conductivity (3500 W/mk), make single-wall carbon nanotubes a promising channel material [100-102]. The non-vacuum and low processing temperature of SWNTs allow for the direct deposition on flexible substrates [103].

The fabrication processes are grouped into two categories; (1) the solution process, including printing [103] and solution-based coating techniques [104], such as spray coating [105] and drop-casting [106]; and (2) dry processes, such as Chemical Vapor Deposition (CVD) [107]. Different applications have been demonstrated for flexible SWCNT TFTs, including integrated circuits [108], sensors [109,110], light-emitting diodes [111], and touch panels [112]. While the mobility of a uniform network of SWCNTs can reach as high as $10,000 \mathrm{~cm}^{2} / \mathrm{Vs}$, the reported mobilities of flexible devices is limited to 10 to $100 \mathrm{~cm}^{2} /$ Vs resulting from a random distribution of nanotubes across the channel [100]. Devices based on SWCNT channel materials suffer from poor reproducibility due to limitations over the synthesis of homogeneous structures and difficulties in the controllable formation of SWCNT assemblies over large areas [113].

The very first flexible SWCNT TFT, fabricated on a $50 \mu \mathrm{m}$ polyimide substrate, was demonstrated by Rogers et al. in 2008. Nearly 100 transistors were implemented on a plastic substrate and showed no significant changes when bent, with the bending radius as low as $5 \mathrm{~mm}$. Three years later, Javey et al. fabricated a large-scale array of SWCNT TFTs on a 24- $\mu \mathrm{m}$ PI substrate, which became stretchable by the formation of a honeycomb mesh 
structure made via direct laser patterning. The bending radii reached $2 \mathrm{~mm}$ thanks to the thinner substrate and the mesh structure. In 2012, Javey et al. presented a thinner TFT with a total thickness of $12.105-\mu \mathrm{m}$, which resulted in a bending radius of $1.27 \mathrm{~mm}$. The thinnest and the most flexible SWCNT TFT was demonstrated in 2016 with a total thickness of $1.476 \mu \mathrm{m}$ and a bending radius of $40 \mu \mathrm{m}$. The TFT film showed little degradation under $67 \%$ compressive strain. Inverters, and NAND and NOR gates were also realized, and showed negligible performance changes under $33 \%$ compressive strain. Figure 9 shows the trend of total device thickness and bending radius of the SWCNT TFTs [114-117]. Table 4 summarizes the main electrical and mechanical properties of the SWCNT TFTs shown in Figure 9, with Figure 10 showing a recent example of flexible CNT TFTs.

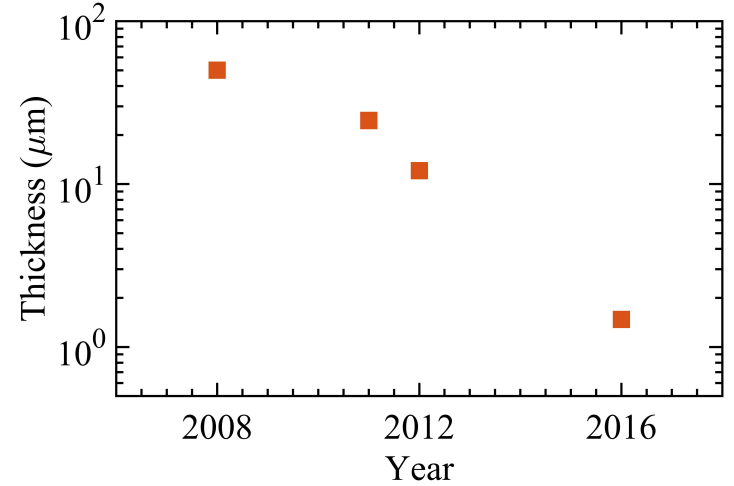

(a)

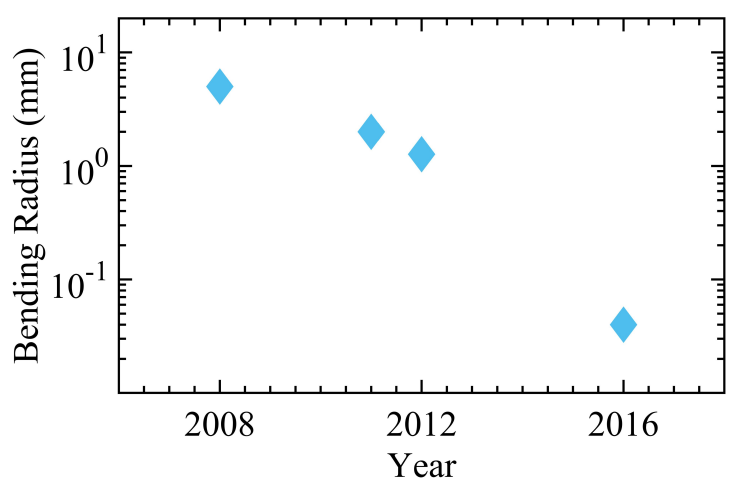

(b)

Figure 9. The progress of SWCNT TFTs with (a) the total thickness and (b) the bending radius.

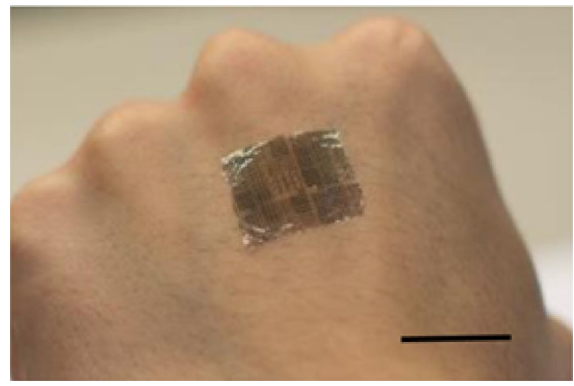

(a)

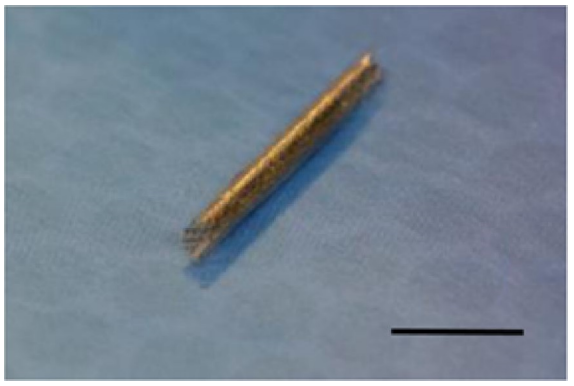

(b)

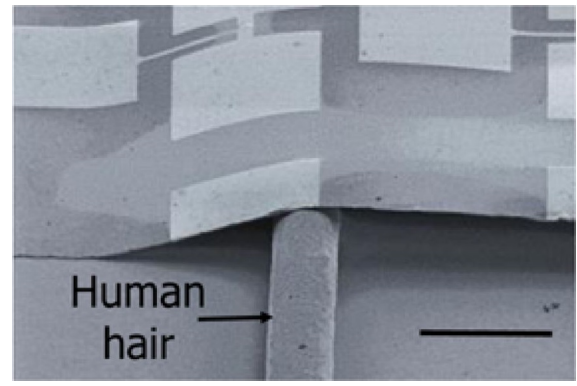

(c)

Figure 10. Ultrathin and flexible carbon nanotube electronic sheet, (a) laminated onto human skin, and (b) rolled-up. (c) SEM image of the CNT film laminated over a human hair. Scale bars are (a) $2 \mathrm{~cm},(\mathbf{b}) 1 \mathrm{~cm}$, and (c) $150 \mu \mathrm{m}$. [117]. Reproduced with permission.

Table 4. The detailed properties of the SWCNT TFTs in Figure 9.

\begin{tabular}{|c|c|c|c|c|c|c|c|c|c|}
\hline $\begin{array}{c}\text { Publication } \\
\text { Year }\end{array}$ & $\begin{array}{c}\text { Bending } \\
\text { Radius } \\
(\mathrm{mm})\end{array}$ & $\begin{array}{c}\text { Total } \\
\text { Thickness } \\
(\mu \mathrm{m})\end{array}$ & $\begin{array}{c}\text { ON/OFF } \\
\text { Ratio }\end{array}$ & $\begin{array}{c}\text { Channel } \\
\text { Width/Length }\end{array}$ & $\begin{array}{l}\text { Mobility } \\
\left(\mathrm{cm}^{2} / \mathrm{Vs}\right)\end{array}$ & Substrate & $\begin{array}{c}\text { Substrate } \\
\text { Thickness } \\
\quad(\mu \mathrm{m})\end{array}$ & Dielectric & Reference \\
\hline 2008 & 5 & $>50$ & $10^{5}$ & $5 / 100$ & 80 & PI & 50 & \multirow{4}{*}{$\begin{array}{c}\mathrm{HfO}_{2} \\
\mathrm{Al}_{2} \mathrm{O}_{3} \text { and } \\
\mathrm{SiO}_{x} \\
\mathrm{Al}_{2} \mathrm{O}_{3} \text { and } \\
\mathrm{SiO}_{x} \\
\mathrm{Al}_{2} \mathrm{O}_{3} \text { and } \\
\mathrm{SiO}_{2}\end{array}$} & [114] \\
\hline 2011 & 2 & 24.58 & $10^{4}$ & $250 / 3$ & $20-30$ & PI & 24 & & [115] \\
\hline 2012 & 1.27 & 12.105 & 400 & $3 / 4$ & 55 & PI & 12 & & [116] \\
\hline 2016 & 0.04 & 1.476 & $10^{6}$ & $100 / 10$ & 12.04 & PET & 1.4 & & [117] \\
\hline
\end{tabular}




\section{Organic Semiconductors}

The first organic TFTs were demonstrated in 1986, fabricated on a silicon substrate with recorded carrier mobilities close to $10^{-5} \mathrm{~cm}^{2} / \mathrm{Vs}$ [118]. In 1994, the first flexible Organic Field Effect Transistor (OFET) was demonstrated, with the device fabricated on a $1.5 \mu \mathrm{m}$ thin PET substrate [119]. Anthopoulos et al. reviewed the reported mobility of fabricated OFETs over the past 30 years and showed that the maximum mobilities for p-type and n-type organic semiconductors were typically below 20 and $10 \mathrm{~cm}^{2} / \mathrm{Vs}$, respectively [13]. Organic field-effect transistors are implemented with four major structures: (1) single gates, including top gate and bottom gate structures, (2) dual gates to improve charge carrier modulation, (3) vertical channel structures, and (4) cylindrical gate structures [35].

The ON/OFF ratio can be as high as $10^{6}$, and the leakage current can be as low as one pA $[120,121]$. Vacuum evaporation techniques and solution-based processing are two major deposition methods for organic materials, with the former typically providing higher carrier mobility compared with the latter [122-124]. However, solution-based deposition methods are beneficial for large-area electronics realization, while the process temperature is low (typically room temperature) and keeps the costs low as well [125].

Flexible OFETs are used for various applications, including displays [126], tags [127], sensors [128], wearable devices [129], integrated circuits [130], and medical devices [131]. Despite the advances in organic semiconductors, the carrier mobilities of OFETs are much lower than other technologies that limit high-speed applications. Yet, with p- and ntype organic semiconductors available, complimentary organic circuits have been shown, something that is yet to be demonstrated for other flexible inorganic technologies.

Bonfiglio et al. demonstrated the earliest OFETs fabricated on a flexible substrates. They presented various types of devices on biaxially oriented PET (known as Mylar) using Pentacene as the semiconductor. Bonfiglio continued demonstrating organic transistors, including solution processed, complimentary (p- and n-type), and transparent devices [132-134]. In 2010, Someya et al. reported an OFET fabricated directly on a $12.5-\mu \mathrm{m}$ thick PI that was bendable down to $0.1 \mathrm{~mm}$.

Three years later, the same group demonstrated a device with a total thickness of approximately $2 \mu \mathrm{m}$ using dinaphtho[2,3-b:2',3'-f]thieno[3,2-b]thiophene (DNTT) as the organic semiconductor. The device could endure $230 \%$ tensile strain, while the bending radius was as low as $5 \mu \mathrm{m}$. In 2016, Someya et al. demonstrated the thinnest OFET to date, with a total device thickness of $270 \mu \mathrm{m}$ and a bending radius of $1.5 \mu \mathrm{m}$. The device is the thinnest and the most bendable reported TFT of any technology and material.

The following year, Chan et al. fabricated OFETs using ultra-thin substrates. While the bending radius remained unchanged, the devices were shown surviving sterilization in $100{ }^{\circ} \mathrm{C}$ boiling water or steam, without much change to their electrical characteristics. Figure 11 demonstrates the information regarding total thickness and the bending radii for the papers in this section [16,135-142]. Table 5 lists the main electrical and mechanical properties as well, with Figure 12 showing an example of flexible organic semiconductor TFTs. 


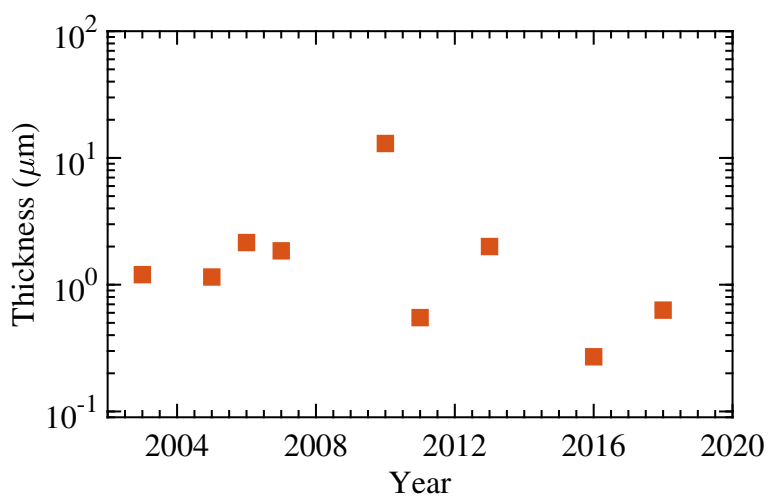

(a)

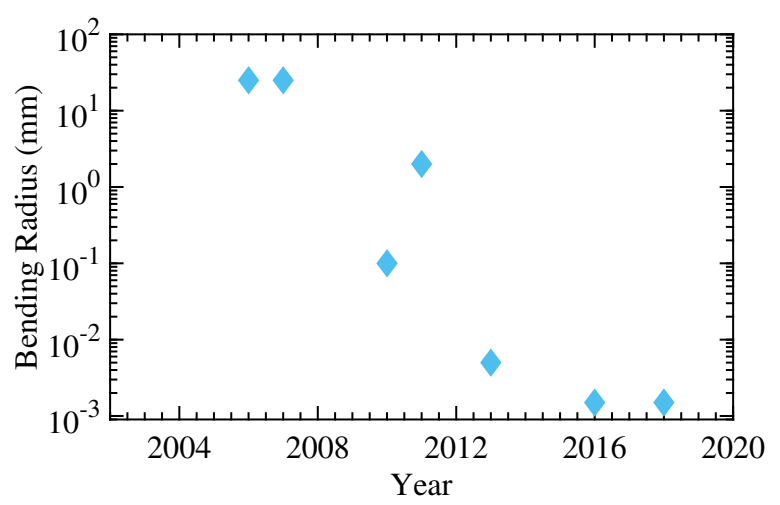

(b)

Figure 11. The progress of organic TFTs with (a) the total thickness and (b) the bending radius.

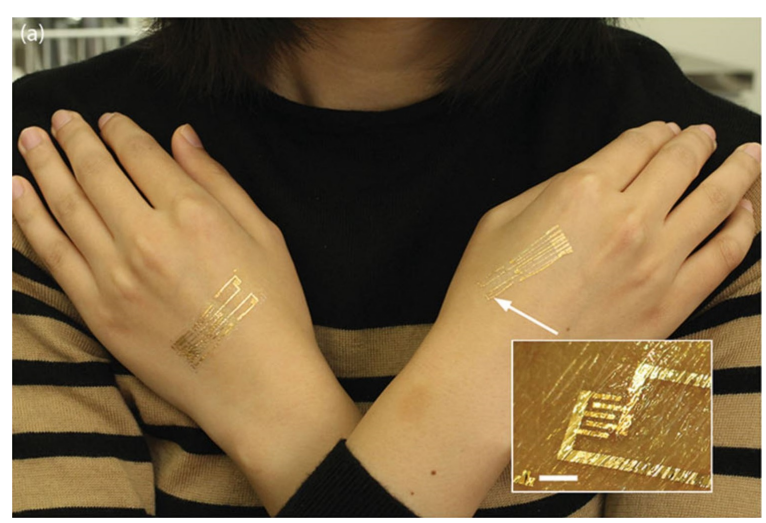

(a)

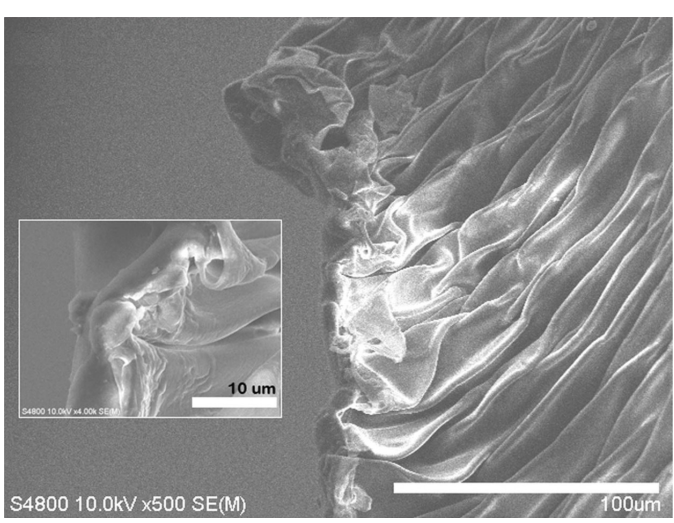

(b)

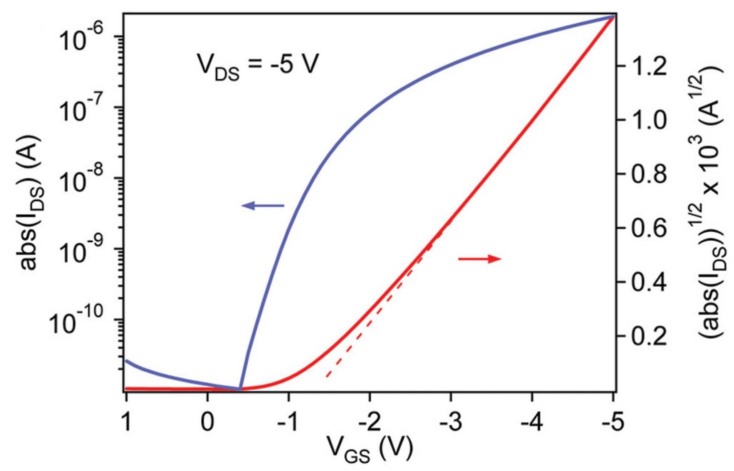

(c)

Figure 12. Ultrathin, flexible, and biocompatible organic electronic TFT, (a) shown laminated on human skin. The inset shows a zoomed view of a tactile sensor, with skin grooves visible. The scale bar is $2 \mathrm{~mm}$. (b) SEM image indicating ultra-small film wrinkles. The scale bars are $100 \mu \mathrm{m}$ in the main image, and $10 \mu \mathrm{m}$ in the inset. (c) Transfer curve of organic TFT. [141]. Reproduced with permission. 
Table 5. The detailed properties of the organic TFTs in Figure 11.

\begin{tabular}{|c|c|c|c|c|c|c|c|c|c|c|}
\hline $\begin{array}{c}\text { Publication } \\
\text { Year }\end{array}$ & $\begin{array}{c}\text { Bending } \\
\text { Radius (mm) }\end{array}$ & $\begin{array}{c}\text { Total } \\
\text { Thickness } \\
(\mu \mathrm{m})\end{array}$ & $\begin{array}{c}\text { ON/OFF } \\
\text { Ratio }\end{array}$ & $\begin{array}{c}\text { Channel } \\
\text { Width/Length }\end{array}$ & $\begin{array}{l}\text { Mobility } \\
\left(\mathrm{cm}^{2} / \mathrm{Vs}\right)\end{array}$ & Substrate & $\begin{array}{c}\text { Substrate } \\
\text { Thickness } \\
(\mu \mathrm{m})\end{array}$ & Dielectric & Semiconductor & Reference \\
\hline 2003 & N/A & 1.2 & $>10^{3}$ & $60,000 / 20$ & $10^{-4}$ & Mylar & 0.9 & Mylar & Pentacene & [135] \\
\hline 2005 & N/A & 1.15 & N/A & $210,000 / 70$ & $5 \times 10^{-4}$ & Mylar & 0.9 & Mylar & Pentacene & [136] \\
\hline 2006 & 25 & 2.15 & N/A & $5000 / 25$ & N/A & Mylar & 1.9 & Mylar & Pentacene & [137] \\
\hline 2007 & 25 & 1.85 & N/A & $5000 / 25$ & N/A & Mylar & 1.6 & Mylar & Pentacene & [138] \\
\hline 2010 & 0.1 & 13 & $\begin{array}{l}10^{7} \text { and } \\
10^{5}\end{array}$ & $500 / 50$ & 0.5 and 0.1 & PI & 12.5 & $\mathrm{AlO}_{x}$ & $\begin{array}{l}\text { Pentacene and } \\
\text { F16CuPc }\end{array}$ & [139] \\
\hline 2011 & 2 & 0.55 & $>10^{3}$ & $5000 / 5$ & $\begin{array}{c}0.04 \pm 0.02 \\
0.03 \pm 0.02 \\
\text { and } \\
0.03 \pm 0.01\end{array}$ & Parylene & 0.4 & Parylene & $\begin{array}{l}\text { Pentacene, TIPS, } \\
\text { and N1400 }\end{array}$ & [140] \\
\hline 2013 & 0.005 & 2 & $>10^{7}$ & $500 / 40$ & 3 & PEN & 1.2 & $\mathrm{AlO}_{x}$ & DNTT & [16] \\
\hline 2016 & 0.0015 & 0.27 & $10^{5}$ & $1000 / 100$ & 0.34 & Parylene & 0.06 & Parylene & DNTT & [141] \\
\hline 2018 & 0.0015 & 0.63 & $>10^{5}$ & 35 & $4.16 \pm 0.73$ & PAN & 0.18 & $\mathrm{Al}_{2} \mathrm{O}_{3}$ & DPh-BBTNDT & [142] \\
\hline
\end{tabular}

\section{Comparison of Semiconducting Technologies}

Different technologies offer different benefits and drawbacks. For instance, while poly-Si offers the highest mobilities of thin and flexible transistors, they lag in flexibility (expressed as bending radii) compared to other technologies. Additionally they require somewhat higher processing temperatures. CNTs offer low processing temperatures, very low bending radii, and relatively high mobilities.

Organic semiconductors offer the highest flexibility with the lowest bending radii. However, they offer relatively low carrier mobilities. Additionally, they are typically susceptible to environmental degradation (due to the exposure of oxygen, moisture, and UV) and, hence, need to be encapsulated. They are also the only technology that offers both p- and n-type, thus,enabling low-power complimentary electronics. Table 6, Figures 13 and 14 briefly summarizes all the technologies presented in this work. The non-monotonic nature of the figures is due to the fact that new demonstrations of thicker TFTs would result devices with smaller bending radii, or vice versa.

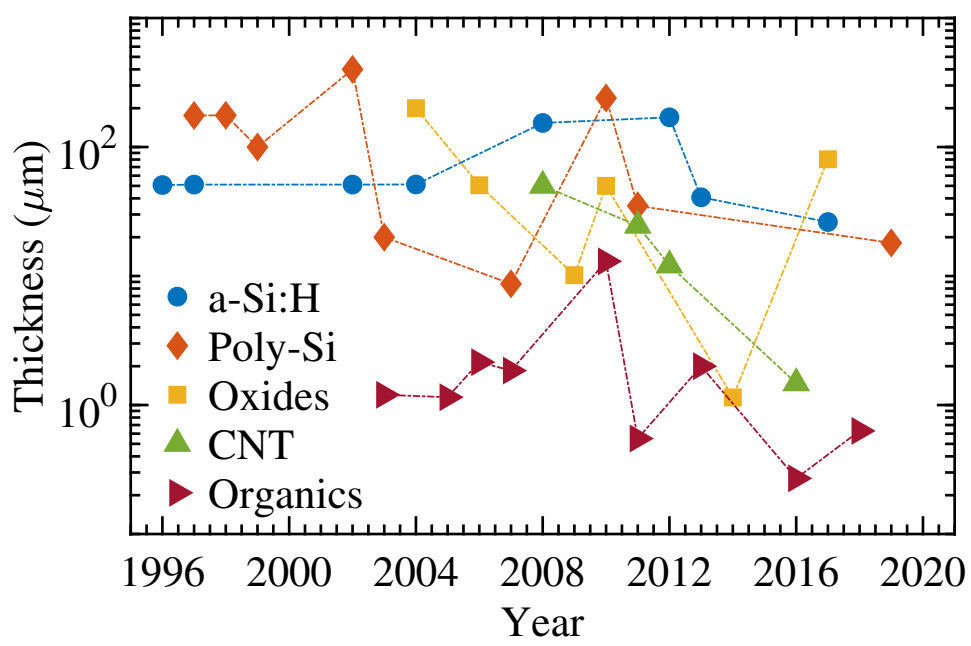

Figure 13. The comparison of thickness over a-Si:H, poly-Si, oxides, CNTs, and organic semiconducting technologies. 


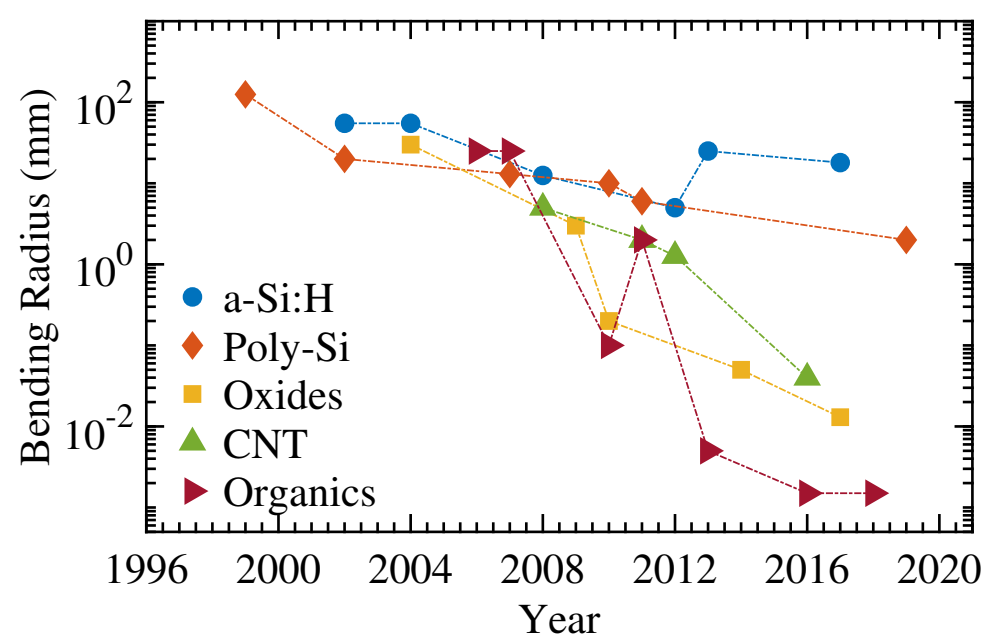

Figure 14. The comparison of bending radius over a-Si:H, poly-Si, oxides, CNTs, and organic semiconducting technologies.

Table 6. Comparison of semiconducting technologies.

\begin{tabular}{ccccccc}
\hline Technology & Semiconductor & $\begin{array}{c}\text { Total Thickness } \\
(\boldsymbol{\mu} \mathbf{m})\end{array}$ & $\begin{array}{c}\text { Bending Radius } \\
(\mathbf{m m})\end{array}$ & $\begin{array}{c}\text { Mobility } \\
\left(\mathbf{c m}^{2} / \mathbf{V s}\right)\end{array}$ & $\begin{array}{c}\text { Process } \\
\text { Temperature }\left({ }^{\circ} \mathbf{C}\right)\end{array}$ & Reference \\
\hline a-Si:H & & 26.22 & 18 & 0.031 & 250 & {$[54]$} \\
Poly-Si & & 18.05 & 2 & 80 & 230 & {$[71]$} \\
Oxides & IGZO & 1.4 & 1.4 & 0.8 & 300 & {$[96]$} \\
CNT & & 1.476 & 0.04 & 12.04 & 90 & {$[117]$} \\
Organics & DNTT & 0.27 & 0.0015 & 0.34 & 120 & {$[141]$} \\
\hline
\end{tabular}

\section{Conclusions}

Flexible electronics have recently gained a considerable amount of attention due to the evolution of new applications that require stretchable and bendable electrical circuits and components. The readers in the field certainly can benefit from an overview regarding the categories of flexible semiconductors, the dominant properties, and the progress of thickness and bendability.

This brief review draws attention to the available flexible electronic technologies and offers a comparison between them all. Flexible TFTs based on five categories (a-Si, Poly-Si, oxides, CNTs, and organic materials) were studied in detail. For every class, the thickness and bending radii trends were investigated through a selected number of works showing the meaningful progress of increases in bendability resulting from the decreases in the total device thickness, including the substrate.

The results demonstrate organic TFTs as the thinnest and the most bendable flexible devices because the Young's modulus of organic materials is three orders of magnitude is lower than other materials. Despite the promising mechanical properties of organic materials, they suffer from poor electrical properties. However, the advances in new organic material synthesis provide a bright future for these materials.

Amorphous silicon is the dominant technology in flexible displays due to the low processing temperature and uniformity; however, the carrier mobility has restricted highspeed applications. Polycrystalline silicon, CNTs, and oxides have shown carrier mobilities as high as $100 \mathrm{~cm}^{2} / \mathrm{Vs}$; however, the total thickness of devices, limited dielectric varieties, and mechanical properties of TFT layers has restricted the minimum bending radius.

Author Contributions: R.A.N. conceived the study; M.J.M.H. and R.A.N. wrote and edited the paper; All authors have read and agreed to the published version of the manuscript.

Funding: This work was partially supported by the Purdue Polytechnic's Realizing the Digital Enterprise graduate fellowship.

Acknowledgments: The authors would like to acknowledge the help of the whole LOBE team. 
Conflicts of Interest: The authors declare no conflict of interest.

\section{References}

1. Nathan, A.; Chalamala, B. Special Issue on Flexible Electronics Technology, Part II: Materials and Devices. Proc. IEEE 2005, 93, 1391-1393. [CrossRef]

2. Khan, Y.; Garg, M.; Gui, Q.; Schadt, M.; Gaikwad, A.; Han, D.; Yamamoto, N.A.D.; Hart, P.; Welte, R.; Wilson, W.; et al. Flexible Hybrid Electronics: Direct Interfacing of Soft and Hard Electronics for Wearable Health Monitoring. Adv. Funct. Mater. 2016, 26, 8764-8775. [CrossRef]

3. Pu, X.; Li, L.; Song, H.; Du, C.; Zhao, Z.; Jiang, C.; Cao, G.; Hu, W.; Wang, Z.L. A Self-Charging Power Unit by Integration of a Textile Triboelectric Nanogenerator and a Flexible Lithium-Ion Battery for Wearable Electronics. Adv. Mater. 2015, 27, $2472-2478$. [CrossRef]

4. Zhou, L.; Wanga, A.; Wu, S.C.; Sun, J.; Park, S.; Jackson, T.N. All-organic active matrix flexible display. Appl. Phys. Lett. 2006, 88, 083502. [CrossRef]

5. Rogers, J.A.; Someya, T.; Huang, Y. Materials and Mechanics for Stretchable Electronics. Science 2010, 327, 1603-1607. [CrossRef] [PubMed]

6. Sekitani, T.; Kaltenbrunner, M.; Yokota, T.; Someya, T. 11.2: Invited Paper: Imperceptible Electronic Skin. SID Symp. Digest Tech. Pap. 2014, 45, 122-125. [CrossRef]

7. Sun, Y.; Rogers, J. Inorganic Semiconductors for Flexible Electronics. Adv. Mater. 2007, 19, 1897-1916. [CrossRef]

8. Lee, J.K.; Lim, Y.S.; Park, C.H.; Park, Y.I.; Kim, C.D.; Hwang, Y.K. a-Si:H Thin-Film Transistor-Driven Flexible Color E-Paper Display on Flexible Substrates. IEEE Electron Device Lett. 2010, 31, 833-835. [CrossRef]

9. Huang, J.J.; Chen, Y.P.; Huang, Y.S.; Hu, G.R.; Lin, C.W.; Chen, Y.J.; Lee, P.F.; Tsai, C.J.; Liu, C.J.; Yao, H.C.; et al. 58.1: A 4.1-Inch Flexible QVGA AMOLED Using a Microcrystalline-Si:H TFT on a Polyimide Substrate. SID Symp. Digest Tech. Pap. 2009, 40, 866-869. [CrossRef]

10. Ito, M.; Kon, M.; Ishizaki, M.; Sekine, N. A flexible active-matrix TFT array with amorphous oxide semiconductors for electronic paper. In Proceedings of the 12th International Display Workshops in Conjunction with Asia Display, IDW/AD'05, Takamatsu, Japan, 6-9 December 2005; pp. 845-846.

11. Chen, Y.; Au, J.; Kazlas, P.; Ritenour, A.; Gates, H.; Mccreary, M. Flexible active-matrix electronic ink display. Nature 2003, $423,136$. [CrossRef]

12. Rogers, J.A.; Bao, Z.; Baldwin, K.; Dodabalapur, A.; Crone, B.; Raju, V.R.; Kuck, V.; Katz, H.; Amundson, K.; Ewing, J.; et al. Paper-like electronic displays: Large-area rubber-stamped plastic sheets of electronics and microencapsulated electrophoretic inks. Proc. Natl. Acad. Sci. USA 2001, 98, 4835-4840. [CrossRef] [PubMed]

13. Petti, L.; Münzenrieder, N.; Vogt, C.; Faber, H.; Büthe, L.; Cantarella, G.; Bottacchi, F.; Anthopoulos, T.D.; Tröster, G. Metal oxide semiconductor thin-film transistors for flexible electronics. Appl. Phys. Rev. 2016, 3, 021303. [CrossRef]

14. Liu, H.; Jian, R.; Chen, H.; Tian, X.; Sun, C.; Zhu, J.; Yang, Z.; Sun, J.; Wang, C. Application of Biodegradable and Biocompatible Nanocomposites in Electronics: Current Status and Future Directions. Nanomaterials 2019, 9, 950. [CrossRef] [PubMed]

15. Oh, J.Y.; Rondeau-Gagné, S.; Chiu, Y.C.; Chortos, A.; Lissel, F.; Wang, G.J.N.; Schroeder, B.C.; Kurosawa, T.; Lopez, J.; Katsumata, T.; et al. Intrinsically stretchable and healable semiconducting polymer for organic transistors. Nature 2016, 539, 411-415. [CrossRef] [PubMed]

16. Kaltenbrunner, M.; Sekitani, T.; Reeder, J.; Yokota, T.; Kuribara, K.; Tokuhara, T.; Drack, M.; Schwödiauer, R.; Graz, I.; BauerGogonea, S.; et al. An ultra-lightweight design for imperceptible plastic electronics. Nature 2013, 499, 458-463. [CrossRef] [PubMed]

17. Nawrocki, R.A. Super- and Ultrathin Organic Field-Effect Transistors: from Flexibility to Super- and Ultraflexibility. Adv. Funct. Mater. 2019, 29, 1906908. [CrossRef]

18. Baran, D.; Corzo, D.; Blazquez, G. Flexible Electronics: Status, Challenges and Opportunities. Front. Electron. 2020, 1, 2. [CrossRef]

19. Nawrocki, R.A.; Jin, H.; Lee, S.; Yokota, T.; Sekino, M.; Someya, T. Self-Adhesive and Ultra-Conformable, Sub-300 nm Dry Thin-Film Electrodes for Surface Monitoring of Biopotentials. Adv. Funct. Mater. 2018, 28, 1803279. [CrossRef]

20. Bock, K. Polymer Electronics Systems - Polytronics. Proc. IEEE 2005, 93, 1400-1406. [CrossRef]

21. Allen, K. Reel to Real: Prospects for Flexible Displays. Proc. IEEE 2005, 93, 1394-1399. [CrossRef]

22. Xu, H.; Luo, D.; Li, M.; Xu, M.; Zou, J.; Tao, H.; Lan, L.; Wang, L.; Peng, J.; Cao, Y. A flexible AMOLED display on the PEN substrate driven by oxide thin-film transistors using anodized aluminium oxide as dielectric. J. Mater. Chem. C 2014, 2, 1255-1259. [CrossRef]

23. Nathan, A.; Chalamala, B. Special Issue on Flexible Electronics Technology, Part 1: Systems and Applications. Proc. IEEE 2005, 93, 1235-1238. [CrossRef]

24. Münzenrieder, N.; Petti, L.; Zysset, C.; Kinkeldei, T.; Salvatore, G.A.; Tröster, G. Flexible Self-Aligned Amorphous InGaZnO Thin-Film Transistors With Submicrometer Channel Length and a Transit Frequency of $135 \mathrm{MHz}$. IEEE Trans. Electron Devices 2013, 60, 2815-2820. [CrossRef]

25. Cherenack, K.H.; Kattamis, A.Z.; Hekmatshoar, B.; Sturm, J.C.; Wagner, S. Amorphous-Silicon Thin-Film Transistors Fabricated at $300{ }^{\circ} \mathrm{C}$ on a Free-Standing Foil Substrate of Clear Plastic. IEEE Electron Device Lett. 2007, 28, 1004-1006. [CrossRef] 
26. Yang, C.S.; Smith, L.L.; Arthur, C.B.; Parsons, G.N. Stability of low-temperature amorphous silicon thin film transistors formed on glass and transparent plastic substrates. J. Vacuum Sci. Technol. B Microelectron. Nanometer Struct. Process. Meas. Phenomena 2000, 18, 683-689. [CrossRef]

27. Shim, G.W.; Hong, W.; Cha, J.H.; Park, J.H.; Lee, K.J.; Choi, S.Y. TFT Channel Materials for Display Applications: From Amorphous Silicon to Transition Metal Dichalcogenides. Adv. Mater. 2020, 32, 1907166. [CrossRef] [PubMed]

28. Chang, T.C.; Tsao, Y.C.; Chen, P.H.; Tai, M.C.; Huang, S.P.; Su, W.C.; Chen, G.F. Flexible low-temperature polycrystalline silicon thin-film transistors. Mater. Today Adv. 2020, 5, 100040. [CrossRef]

29. Jeong, J.K. The status and perspectives of metal oxide thin-film transistors for active matrix flexible displays. Semicond. Sci. Technol. 2011, 26, 034008. [CrossRef]

30. Kamiya, T.; Nomura, K.; Hosono, H. Present status of amorphous In-Ga-Zn-O thin-film transistors. Sci. Technol. Adv. Mater. 2010, 11, 044305. [CrossRef] [PubMed]

31. De la Fuente Vornbrock, A.; Almanza-Workman, M.; Dickin, F.; Elder, R.E.; Garcia, R.A.; Holland, E.; Jackson, W.; Jam, M.; Jeans, A.; Kim, H.J.; et al. A comparison of processes and challenges between organic, a-Si:H, and oxide TFTs for active matrix backplanes on plastic. In Proceedings of the 2012 19th International Workshop on Active-Matrix Flatpanel Displays and Devices (AM-FPD), Kyoto, Japan, 4-6 July 2012; pp. 57-60.

32. Che, Y.; Chen, H.; Gui, H.; Liu, J.; Liu, B.; Zhou, C. Review of carbon nanotube nanoelectronics and macroelectronics. Semicond. Sci. Technol. 2014, 29, 073001. [CrossRef]

33. Wang, C.; Takei, K.; Takahashi, T.; Javey, A. Carbon nanotube electronics-Moving forward. Chem. Soc. Rev. 2013, 42, 2592-2609. [CrossRef]

34. Liu, B.; Wang, C.; Liu, J.; Che, Y.; Zhou, C. Aligned carbon nanotubes: from controlled synthesis to electronic applications. Nanoscale 2013, 5, 9483-9502. [CrossRef]

35. Kumar, B.; Kaushik, B.K.; Negi, Y.S. Organic Thin Film Transistors: Structures, Models, Materials, Fabrication, and Applications: A Review. Polym. Rev. 2014, 54, 33-111. [CrossRef]

36. Paterson, A.F.; Singh, S.; Fallon, K.J.; Hodsden, T.; Han, Y.; Schroeder, B.C.; Bronstein, H.; Heeney, M.; McCulloch, I.; Anthopoulos, T.D. Recent Progress in High-Mobility Organic Transistors: A Reality Check. Adv. Mater. 2018, 30, 1801079. [CrossRef]

37. Okaniwa, H.; Nakatani, K.; Asano, M.; Suzuki, K.; Yano, M.; Hirasaka, M.; Hamakawa, Y. Hydrogenated amorphous silicon solar cell on organic polymer substrate. IEICE Trans. (1976-1990) 1983, 66, 34-38.

38. Tsukada, T. Amorphous silicon thin-film transistors. J. Non-Cryst. Solids 1993, 164-166, 721-726. [CrossRef]

39. Long, K.; Kattamis, A.; Cheng, I.C.; Gleskova, H.; Wagner, S.; Sturm, J. Stability of amorphous-silicon TFTs deposited on clear plastic substrates at 250/spl deg/C to 280/spl deg/C. IEEE Electron Device Lett. 2006, 27, 111-113. [CrossRef]

40. Street, R.A. Trapping parameters of dangling bonds in hydrogenated amorphous silicon. Appl. Phys. Lett. 1982, 41, 1060-1062. [CrossRef]

41. Feenstra, K.F.; Schropp, R.E.I.; Van der Weg, W.F. Deposition of amorphous silicon films by hot-wire chemical vapor deposition. J. Appl. Phys. 1999, 85, 6843-6852. [CrossRef]

42. Schropp, R. Industrialization of Hot Wire Chemical Vapor Deposition for thin film applications. Thin Solid Films 2015, 595, 272-283. [CrossRef]

43. Street, R.A. Thin-Film Transistors. Adv. Mater. 2009, 21, 2007-2022. [CrossRef]

44. Kuo, Y. Thin Film Transistor Technology-Past, Present, and Future. Interface Mag. 2013, 22, 55-61. [CrossRef]

45. Van Berkel, C.; Powell, M.J. Resolution of amorphous silicon thin-film transistor instability mechanisms using ambipolar transistors. Appl. Phys. Lett. 1987, 51, 1094-1096. [CrossRef]

46. Wen, Y.; Liu, Y.; Guo, Y.; Yu, G.; Hu, W. Experimental Techniques for the Fabrication and Characterization of Organic Thin Films for Field-Effect Transistors. Chem. Rev. 2011, 111, 3358-3406. [CrossRef] [PubMed]

47. Gleskova, H.; Konenkamp, R.; Wagner, S. Electrophotographically patterned thin-film silicon transistors. IEEE Electron Device Lett. 1996, 17, 264-266. [CrossRef]

48. Gleskova, H.; Wagner, S.; Zhang, Q.; Shen, D.S. Via hole technology for thin-film transistor circuits. IEEE Electron Device Lett. 1997, 18, 523-525. [CrossRef]

49. Hsu, P.I.; Gleskova, H.; Huang, M.; Suo, Z.; Wagner, S.; Sturm, J.C. Amorphous Si TFTs on plastically deformed spherical domes. J. Non-Cryst. Solids 2002, 299-302, 1355-1359.[CrossRef]

50. Hsu, P.H.I.; Member, S.; Huang, M.; Gleskova, H.; Xi, Z.; Suo, Z.; Wagner, S.; Sturm, J.C. Effects of Mechanical Strain on TFTs on Spherical Domes. IEEE Trans. Electron Devices 2004, 51, 371-377. [CrossRef]

51. Kim, S.H.; Cheon, J.H.; Kim, E.B.; Bae, J.H.; Hur, J.H.; Jang, J. High-performance hydrogenated amorphous silicon TFT on flexible metal foil with polyimide planarization. J. Non-Cryst. Solids 2008, 354, 2529-2533. [CrossRef]

52. Hoehla, S.; Garner, S.; Hohmann, M.; Kuhls, O.; Li, X.; Schindler, A.; Fruehauf, N. Active matrix color-LCD on $75 \mu \mathrm{m}$ thick flexible glass substrates. IEEE/OSA J. Disp. Technol. 2012, 8, 309-316. [CrossRef]

53. Huang, J.J.; Chen, C.N. Effect of electrical and mechanical stresses of low temperature a-Si:H thin film transistors fabricated on polyimide and glass substrates. Thin Solid Films 2013, 529, 454-458. [CrossRef]

54. Kim, M.; Oh, H.; Park, S.; Cho, K.; Kim, S. Mechanical strain-induced defect states in amorphous silicon channel layers of thin-film transistors. Thin Solid Films 2017, 641, 43-46. [CrossRef] 
55. Kallel, S.; Semmache, B.; Lemiti, M.; Dubois, C.; Jaffrezic, H.; Laugier, A. Growth and physical properties of in situ phosphorusdoped RTLPCVD polycrystalline silicon thin films. Mater. Sci. Semicond. Process. 1998, 1, 299-302. [CrossRef]

56. Hatalis, M.; Greve, D. High-performance thin-film transistors in low-temperature crystallized LPCVD amorphous silicon films. IEEE Electron Device Lett. 1987, 8, 361-364. [CrossRef]

57. Sameshima, T.; Usui, S.; Sekiya, M. XeCl Excimer laser annealing used in the fabrication of poly-Si TFT's. IEEE Electron Device Lett. 1986, 7, 276-278. [CrossRef]

58. Matsuo, N.; Heya, A.; Hamada, H. Review-Technology Trends of Poly-Si TFTs from the Viewpoints of Crystallization and Device Performance. ECS J. Solid State Sci. Technol. 2019, 8, P239-P252. [CrossRef]

59. Brotherton, S.D. Polycrystalline silicon thin film transistors. Semicond. Sci. Technol. 1995, 10, 721-738. [CrossRef]

60. Yoshikawa, T.; Yagi, T.; Oka, N.; Jia, J.; Yamashita, Y.; Hattori, K.; Seino, Y.; Taketoshi, N.; Baba, T.; Shigesato, Y. Thermal conductivity of amorphous indium-gallium-zinc oxide thin films. Appl. Phys. Express 2013, 6, 021101. [CrossRef]

61. Tai, Y.C.; Mastrangelo, C.H.; Muller, R.S. Thermal conductivity of heavily doped low-pressure chemical vapor deposited polycrystalline silicon films. J. Appl. Phys. 1988, 63, 1442-1447. [CrossRef]

62. Herlogsson, L. Electrolyte-Gated Organic Thin-Film Transistors. Ph.D. Thesis, Linköping University Electronic Press, Linköping, Sweden, 2011.

63. Smith, P.M.; Carey, P.G.; Sigmon, T.W. Excimer laser crystallization and doping of silicon films on plastic substrates. Appl. Phys. Lett. 1997, 70, 342-344. [CrossRef]

64. Theiss, S.; Carey, P.; Smith, P.; Wickboldt, P.; Sigmon, T.; Tung, Y.; King, T.J. Polysilicon thin film transistors fabricated at 100/spl $\mathrm{deg} / \mathrm{C}$ on a flexible plastic substrate. In Proceedings of the International Electron Devices Meeting 1998. Technical Digest (Cat. No. 98CH36217), San Francisco, CA, USA, 6-9 December 1998; pp. 257-260. [CrossRef]

65. Serikawa, T.; Omata, F. High-mobility poly-Si TFT's fabricated on flexible stainless-steel substrates. IEEE Electron Device Lett. 1999, 20, 574-576. [CrossRef]

66. Inoue, S.; Utsunomiya, S.; Saeki, T.; Shimoda, T. Surface-free technology by laser annealing (SUFTLA) and its application to poly-Si TFT-LCDs on plastic film with integrated drivers. IEEE Trans. Electron Devices 2002, 49, 1353-1360. [CrossRef]

67. Lee, Y.; Li, H.; Fonash, S.J. High-performance poly-Si TFT on plastic substrates using a nano-structured separation layer approach. IEEE Electron Device Lett. 2003, 24, 19-21. [CrossRef]

68. Pecora, A.; Maiolo, L.; Cuscuna, M.; Simeone, D.; Minotti, A.; Mariucci, L.; Fortunato, G. Polysilicon Thin Film Transistors on spin-coated Polyimide layer for flexible electronics. In Korea Information Display Society: Proceedings of the Conference; The Korean Information Display Society: Seoul, Korea, 2007; pp. 261-264.

69. An, S.; Lee, J.; Kim, Y.; Kim, T.; Jin, D.; Min, H.; Chung, H.; Kim, S.S. 47.2: 2.8-Inch WQVGA flexible AMOLED using high performance low temperature polysilicon TFT on plastic substrates. In 48th Annual SID Symposium, Seminar, and Exhibition 2010, Display Week 2010; Blackwell Publishing Ltd.: Oxford, UK, 2010; Volume 41, pp. 706-709.

70. Zampetti, E.; Maiolo, L.; Pecora, A.; Maita, F.; Pantalei, S.; Minotti, A.; Valletta, A.; Cuscun, M.; MacAgnano, A.; Fortunato, G.; et al. Flexible sensorial system based on capacitive chemical sensors integrated with readout circuits fully fabricated on ultra thin substrate. Sens. Actuators B Chem. 2011, 155, 768-774. [CrossRef]

71. Park, C.B. Investigation of the electromechanical stability of low temperature polycrystalline silicon thin-film transistors governed by types of stress. Solid-State Electron. 2019, 160, 107616. [CrossRef]

72. Nomura, K.; Ohta, H.; Ueda, K.; Kamiya, T.; Hirano, M.; Hosono, H. Thin-Film Transistor Fabricated in Single-Crystalline Transparent Oxide Semiconductor. Science 2003, 300, 1269-1272. [CrossRef] [PubMed]

73. Nomura, K.; Ohta, H.; Takagi, A.; Kamiya, T.; Hirano, M.; Hosono, H. Room-temperature fabrication of transparent flexible thin-film transistors using amorphous oxide semiconductors. Nature 2004, 432, 488-492. [CrossRef]

74. He, Y.; Wang, X.; Gao, Y.; Hou, Y.; Wan, Q. Oxide-based thin film transistors for flexible electronics. J. Semicond. 2018, $39,011005$. [CrossRef]

75. Fortunato, E.; Barquinha, P.; Martins, R. Oxide Semiconductor Thin-Film Transistors: A Review of Recent Advances. Adv. Mater. 2012, 24, 2945-2986. [CrossRef]

76. Zhang, Y.H.; Mei, Z.X.; Liang, H.L.; Du, X.L. Review of flexible and transparent thin-film transistors based on zinc oxide and related materials. Chin. Phys. B 2017, 26, 047307. [CrossRef]

77. Zeumault, A.; Ma, S.; Holbery, J. Fully inkjet-printed metal-oxide thin-film transistors on plastic. Phys. Status Solidi (a) 2016, 213, 2189-2195. [CrossRef]

78. Jo, J.W.; Kim, J.; Kim, K.T.; Kang, J.G.; Kim, M.G.; Kim, K.H.; Ko, H.; Kim, Y.H.; Park, S.K. Highly Stable and Imperceptible Electronics Utilizing Photoactivated Heterogeneous Sol-Gel Metal-Oxide Dielectrics and Semiconductors. Adv. Mater. 2015, 27, 1182-1188. [CrossRef]

79. Liu, J.; Buchholz, D.B.; Chang, R.P.H.; Facchetti, A.; Marks, T. High-performance flexible transparent thin-film transistors using a hybrid gate dielectric and an amorphous zinc indium tin oxide channel. J. Adv. Mater. 2010, 22, 2333-2337. [CrossRef]

80. Nag, M.; Bhoolokam, A.; Smout, S.; Willegems, M.; Muller, R.; Myny, K.; Schols, S.; Ameys, M.; Genoe, J.; Ke, T.H.; et al. Circuits and AMOLED display with self-aligned a-IGZO TFTs on polyimide foil. J. Soc. Inf. Disp. 2014, 22, 509-517. [CrossRef]

81. Ito, M.; Kon, M.; Miyazaki, C.; Ikeda, N.; Ishizaki, M.; Matsubara, R.; Ugajin, Y.; Sekine, N. Amorphous oxide TFT and their applications in electrophoretic displays. Phys. Status Solidi (a) 2008, 205, 1885-1894. [CrossRef]

82. Li, X.; Jang, J. Stretchable oxide TFT for wearable electronics. Inf. Disp. 2017, 33, 12-39. [CrossRef] 
83. Jung, S.W.; Koo, J.B.; Park, C.W.; Na, B.S.; Oh, J.Y.; Lee, S.S.; Koo, K.W. Flexible nonvolatile memory transistors using indium gallium zinc oxide-channel and ferroelectric polymer poly(vinylidene fluoride-co-trifluoroethylene) fabricated on elastomer substrate. J. Vacuum Sci. Technol. B 2015, 33, 051201. [CrossRef]

84. Kim, S.J.; Jeon, D.B.; Park, J.H.; Ryu, M.K.; Yang, J.H.; Hwang, C.S.; Kim, G.H.; Yoon, S.M. Nonvolatile Memory Thin-Film Transistors Using Biodegradable Chicken Albumen Gate Insulator and Oxide Semiconductor Channel on Eco-Friendly Paper Substrate. ACS Appl. Mater. Interfaces 2015, 7, 4869-4874. [CrossRef]

85. Wang, Z.; Alshammari, F.H.; Omran, H.; Hota, M.K.; Al-Jawhari, H.A.; Salama, K.N.; Alshareef, H.N. All-Oxide Thin Film Transistors and Rectifiers Enabling On-Chip Capacitive Energy Storage. Adv. Electron. Mater. 2019, 5, 1900531. [CrossRef]

86. Choi, J.Y.; Lee, S.Y. Comprehensive review on the development of high mobility in oxide thin film transistors. J. Korean Phys. Soc. 2017, 71, 516-527. [CrossRef]

87. Song, J.; Huang, X.; Han, C.; Yu, Y.; Su, Y.; Lai, P. Recent Developments of Flexible InGaZnO Thin-Film Transistors. Phys. Status Solidi (a) 2021, 218, 2000527. [CrossRef]

88. Jung, S.W.; Choi, J.S.; Park, J.H.; Koo, J.B.; Park, C.W.; Na, B.S.; Oh, J.Y.; Lim, S.C.; Lee, S.S.; Chu, H.Y.; et al. Oxide SemiconductorBased Flexible Organic/Inorganic Hybrid Thin-Film Transistors Fabricated on Polydimethylsiloxane Elastomer. J. Nanosci. Nanotechnol. 2016, 16, 2752-2755. [CrossRef]

89. Erb, R.M.; Cherenack, K.H.; Stahel, R.E.; Libanori, R.; Kinkeldei, T.; Münzenrieder, N.; Tröster, G.; Studart, A.R. Locally Reinforced Polymer-Based Composites for Elastic Electronics. ACS Appl. Mater. Interfaces 2012, 4, 2860-2864. [CrossRef]

90. Dai, M.K.; Lian, J.T.; Lin, T.Y.; Chen, Y.F. High-performance transparent and flexible inorganic thin film transistors: A facile integration of graphene nanosheets and amorphous InGaZnO. J. Mater. Chem. C 2013, 1, 5064-5071. [CrossRef]

91. Jackson, W.B.; Herman, G.S.; Hoffman, R.L.; Taussig, C.; Braymen, S.; Jeffery, F.; Hauschildt, J. Zinc tin oxide transistors on flexible substrates. J. Non-Cryst. Solids 2006, 352, 1753-1755. [CrossRef]

92. Park, J.S.; Kim, T.W.; Stryakhilev, D.; Lee, J.S.; An, S.G.; Pyo, Y.S.; Lee, D.B.; Mo, Y.G.; Jin, D.U.; Chung, H.K. Flexible full color organic light-emitting diode display on polyimide plastic substrate driven by amorphous indium gallium zinc oxide thin-film transistors. Appl. Phys. Lett. 2009, 95, 93-96. [CrossRef]

93. Song, K.; Noh, J.; Jun, T.; Jung, Y.; Kang, H.Y.; Moon, J. Fully Flexible Solution-Deposited ZnO Thin-Film Transistors. Adv. Mater. 2010, 22, 4308-4312. [CrossRef]

94. Salvatore, G.A.; Münzenrieder, N.; Kinkeldei, T.; Petti, L.; Zysset, C.; Strebel, I.; Büthe, L.; Tröster, G. Wafer-scale design of lightweight and transparent electronics that wraps around hairs. Nat. Commun. 2014, 5, 2982. [CrossRef] [PubMed]

95. Cantarella, G.; Vogt, C.; Hopf, R.; Münzenrieder, N.; Andrianakis, P.; Petti, L.; Daus, A.; Knobelspies, S.; Büthe, L.; Tröster, G.; et al. Buckled Thin-Film Transistors and Circuits on Soft Elastomers for Stretchable Electronics. ACS Appl. Mater. Interfaces 2017, 9, 28750-28757. [CrossRef]

96. Yoon, J.; Bae, G.Y.; Yoo, S.; Yoo, J.I.; You, N.H.; Hong, W.K.; Ko, H.C. Deep-ultraviolet sensing characteristics of transparent and flexible IGZO thin film transistors. J. Alloys Compd. 2020, 817, 152788. [CrossRef]

97. Martel, R.; Schmidt, T.; Shea, H.R.; Hertel, T.; Avouris, P. Single- and multi-wall carbon nanotube field-effect transistors. Appl. Phys. Lett. 1998, 73, 2447-2449. [CrossRef]

98. Cui, J.B.; Burghard, M.; Kern, K. Room Temperature Single Electron Transistor by Local Chemical Modification of Carbon Nanotubes. Nano Lett. 2002, 2,117-120. [CrossRef]

99. Wu, Z.; Chen, Z.; Du, X.; Logan, J.M.; Sippel, J.; Nikolou, M.; Kamaras, K.; Reynolds, J.R.; Tanner, D.B.; Hebard, A.F.; et al. Transparent, Conductive Carbon Nanotube Films. Science 2004, 305, 1273-1276. [CrossRef]

100. Kumar, S.; Cola, B.A.; Jackson, R.; Graham, S. A Review of Carbon Nanotube Ensembles as Flexible Electronics and Advanced Packaging Materials. J. Electron. Packag. 2011, 133. [CrossRef]

101. Avouris, P.; Appenzeller, J.; Martel, R.; Wind, S. Carbon nanotube electronics. Proc. IEEE 2003, 91, 1772-1784. [CrossRef]

102. Avouris, P. Carbon nanotube electronics. Chem. Phys. 2002, 281, 429-445. [CrossRef]

103. Hirotani, J.; Ohno, Y. Carbon Nanotube Thin Films for High-Performance Flexible Electronics Applications. Top. Curr. Chem. 2019, 377. [CrossRef]

104. Wang, H.; Luo, J.; Robertson, A.; Ito, Y.; Yan, W.; Lang, V.; Zaka, M.; Schaffel, F.; Rummeli, M.H.; Briggs, G.A.D.; et al. Highperformance field effect transistors from solution processed carbon nanotubes. ACS Nano 2010, 4, 6659-6664. [CrossRef] [PubMed]

105. Jeong, M.; Lee, K.; Choi, E.; Kim, A.; Lee, S.B. Spray-coated carbon nanotube thin-film transistors with striped transport channels. Nanotechnology 2012, 23, 505203. [CrossRef] [PubMed]

106. Shimizu, M.; Fujii, S.; Tanaka, T.; Kataura, H. Effects of surfactants on the electronic transport properties of thin-film transistors of single-wall carbon nanotubes. J. Phys. Chem. C 2013, 117, 11744-11749. [CrossRef]

107. Park, S.; Vosguerichian, M.; Bao, Z. A review of fabrication and applications of carbon nanotube film-based flexible electronics. Nanoscale 2013, 5, 1727-1752. [CrossRef] [PubMed]

108. Sun, D.M.; Timmermans, M.Y.; Tian, Y.; Nasibulin, A.G.; Kauppinen, E.I.; Kishimoto, S.; Mizutani, T.; Ohno, Y. Flexible high-performance carbon nanotube integrated circuits. Nat. Nanotechnol. 2011, 6, 156-161. [CrossRef] [PubMed]

109. Kim, J.; Yoo, H.; Ba, V.A.P.; Shin, N.; Hong, S. Dye-functionalized sol-gel matrix on carbon nanotubes for refreshable and flexible gas sensors. Sci. Rep. 2018, 8, 1-8. [CrossRef] [PubMed] 
110. Laurila, T.; Sainio, S.; Caro, M.A. Hybrid carbon based nanomaterials for electrochemical detection of biomolecules. Progress Mater. Sci. 2017, 88, 499-594. [CrossRef]

111. Yu, Z.; Niu, X.; Liu, Z.; Pei, Q. Intrinsically stretchable polymer light-emitting devices using carbon nanotube-polymer composite electrodes. Adv. Mater. 2011, 23, 3989-3994. [CrossRef]

112. Feng, C.; Liu, K.; Wu, J.S.; Liu, L.; Cheng, J.S.; Zhang, Y.; Sun, Y.; Li, Q.; Fan, S.; Jiang, K. Flexible, stretchable, transparent conducting films made from superaligned carbon nanotubes. Adv. Funct. Mater. 2010, 20, 885-891. [CrossRef]

113. Cai, L.; Wang, C. Carbon Nanotube Flexible and Stretchable Electronics. Nanoscale Res. Lett. 2015, 10. [CrossRef]

114. Cao, Q.; Kim, H.S.; Pimparkar, N.; Kulkarni, J.P.; Wang, C.; Shim, M.; Roy, K.; Alam, M.A.; Rogers, J.A. Medium-scale carbon nanotube thin-film integrated circuits on flexible plastic substrates. Nature 2008, 454, 495-500. [CrossRef]

115. Takahashi, T.; Takei, K.; Gillies, A.G.; Fearing, R.S.; Javey, A. Carbon nanotube active-matrix backplanes for conformal electronics and sensors. Nano Lett. 2011, 11, 5408-5413. [CrossRef]

116. Wang, C.; Chien, J.C.; Takei, K.; Takahashi, T.; Nah, J.; Niknejad, A.M.; Javey, A. Extremely bendable, high-performance integrated circuits using semiconducting carbon nanotube networks for digital, analog, and radio-frequency applications. Nano Lett. 2012, 12, 1527-1533. [CrossRef]

117. Cao, X.; Cao, Y.; Zhou, C. Imperceptible and ultraflexible p-Type transistors and macroelectronics based on carbon nanotubes. ACS Nano 2016, 10, 199-206. [CrossRef]

118. Tsumura, A.; Koezuka, H.; Ando, T. Macromolecular electronic device: Field-effect transistor with a polythiophene thin film. Appl. Phys. Lett. 1986, 49, 1210-1212. [CrossRef]

119. Garnier, F.; Hajlaoui, R.; Yassar, A.; Srivastava, P. All-Polymer Field-Effect Transistor Realized by Printing Techniques. Science 1994, 265, 1684-1686. [CrossRef] [PubMed]

120. Anthony, J.E.; Facchetti, A.; Heeney, M.; Marder, S.R.; Zhan, X. n-Type Organic Semiconductors in Organic Electronics. Adv. Mater. 2010, 22, 3876-3892. [CrossRef]

121. Sirringhaus, H. Reliability of organic field-effect transistors. Adv. Mater. 2009, 21, 3859-3873. [CrossRef]

122. Klauk, H.; Zschieschang, U.; Halik, M. Low-voltage organic thin-film transistors with large transconductance. J. Appl. Phys. 2007, 102, 074514. [CrossRef]

123. Raval, H.N.; Tiwari, S.P.; Navan, R.R.; Mhaisalkar, S.G.; Rao, V.R. Solution-Processed Bootstrapped Organic Inverters Based on P3HT with a High- $k$ Gate Dielectric Material. IEEE Electron Device Lett. 2009, 30, 484-486. [CrossRef]

124. Puigdollers, J.; Voz, C.; Martin, I.; Orpella, A.; Vetter, M.; Alcubilla, R. Pentacene thin-film transistors on polymeric gate dielectric: device fabrication and electrical characterization. J. Non-Cryst. Solids 2004, 338, 617-621. [CrossRef]

125. Buga, C.S.; Viana, J.C. A Review on Materials and Technologies for Organic Large-Area Electronics. Adv. Mater. Technol. 2021, 2001016. [CrossRef]

126. Park, C.B.; Kim, K.M.; Lee, J.E.; Na, H.; Yoo, S.S.; Yang, M.S. Flexible electrophoretic display driven by solution-processed organic TFT with highly stable bending feature. Org. Electron. 2014, 15, 3538-3545. [CrossRef]

127. Cantatore, E.; Geuns, T.C.T.; Gelinck, G.H.; van Veenendaal, E.; Gruijthuijsen, A.F.A.; Schrijnemakers, L.; Drews, S.; de Leeuw, D.M. A 13.56-MHz RFID System Based on Organic Transponders. IEEE J. Solid-State Circuits 2007, 42, 84-92. [CrossRef]

128. Briand, D.; Oprea, A.; Courbat, J.; Bârsan, N. Making environmental sensors on plastic foil. Mater. Today 2011, 14, 416-423. [CrossRef]

129. Takeda, Y.; Hayasaka, K.; Shiwaku, R.; Yokosawa, K.; Shiba, T.; Mamada, M.; Kumaki, D.; Fukuda, K.; Tokito, S. Fabrication of Ultra-Thin Printed Organic TFT CMOS Logic Circuits Optimized for Low-Voltage Wearable Sensor Applications. Sci. Rep. 2016, 6. [CrossRef] [PubMed]

130. Guerin, M.; Daami, A.; Jacob, S.; Bergeret, E.; Benevent, E.; Pannier, P.; Coppard, R. High-Gain Fully Printed Organic Complementary Circuits on Flexible Plastic Foils. IEEE Trans. Electron Devices 2011, 58, 3587-3593. [CrossRef]

131. Yokota, T.; Fukuda, K.; Someya, T. Recent Progress of Flexible Image Sensors for Biomedical Applications. Adv. Mater. 2021, 33, 2004416. [CrossRef] [PubMed]

132. Viola, F.A.; Spanu, A.; Ricci, P.C.; Bonfiglio, A.; Cosseddu, P. Ultrathin, flexible and multimodal tactile sensors based on organic field-effect transistors. Sci. Rep. 2018, 8. [CrossRef]

133. Lai, S.; Casula, G.; Ricci, P.C.; Cosseddu, P.; Bonfiglio, A. All-Organic, Low Voltage, Transparent and Compliant Organic Field-Effect Transistor Fabricated by Means of Large-Area, Cost-Effective Techniques. Appl. Sci. 2020, 10. [CrossRef]

134. Lai, S.; Zucca, A.; Cosseddu, P.; Greco, F.; Mattoli, V.; Bonfiglio, A. Ultra-conformable Organic Field-Effect Transistors and circuits for epidermal electronic applications. Org. Electron. 2017, 46, 60-67. [CrossRef]

135. Bonfiglio, A.; Mameli, F.; Sanna, O. A completely flexible organic transistor obtained by a one-mask photolithographic process. Appl. Phys. Lett. 2003, 82, 3550-3552. [CrossRef]

136. Santato, C.; Manunza, I.; Bonfiglio, A.; Cicoira, F.; Cosseddu, P.; Zamboni, R.; Muccini, M. Tetracene light-emitting transistors on flexible plastic substrates. Appl. Phys. Lett. 2005, 86, 1-3. [CrossRef]

137. Cosseddu, P.; Bonfiglio, A. Soft lithography fabrication of all-organic bottom-contact and top-contact field effect transistors. Appl. Phys. Lett. 2006, 88, 1-3. [CrossRef]

138. Manunza, I.; Bonfiglio, A. Pressure sensing using a completely flexible organic transistor. Biosens. Bioelectron. 2007, 22, 2775-2779. [CrossRef] 
139. Sekitani, T.; Zschieschang, U.; Klauk, H.; Someya, T. Flexible organic transistors and circuits with extreme bending stability. Nat. Mater. 2010, 9, 1015-1022. [CrossRef]

140. Cosseddu, P.; Piras, A.; Bonfiglio, A. Fully deformable organic thin-film transistors with moderate operation voltage. IEEE Trans. Electron Devices 2011, 58, 3416-3421. [CrossRef]

141. Nawrocki, R.A.; Matsuhisa, N.; Yokota, T.; Someya, T. 300-nm Imperceptible, Ultraflexible, and Biocompatible e-Skin Fit with Tactile Sensors and Organic Transistors. Adv. Electron. Mater. 2016, 2, 2-5. [CrossRef]

142. Ji, X.; Zhou, P.; Zhong, L.; Xu, A.; Tsang, A.C.; Chan, P.K. Smart Surgical Catheter for C-Reactive Protein Sensing Based on an Imperceptible Organic Transistor. Adv. Sci. 2018, 5, 1-8. [CrossRef] 